\title{
A Review of Climate Change Impacts to Oil Sector Critical Services and Suggested Recommendations for Industry Uptake
}

\author{
Theodoros Katopodis ${ }^{1,2, *(\mathbb{D})}$ and Athanasios Sfetsos ${ }^{1}$ (D) \\ 1 Environmental Research Laboratory, NCSR “Demokritos”, 15341 Agia Paraskevi, Greece; \\ ts@ipta.demokritos.gr \\ 2 Department of Mechanical Engineering \& Aeronautics University of Patras, 26500 Patras, Greece \\ * Correspondence: tkatopo@ipta.demokritos.gr
}

Received: 23 October 2019; Accepted: 23 November 2019; Published: 26 November 2019

\begin{abstract}
Climate change already has far-reaching impacts on the oil industry, putting the operation, reliability, and growth of the sector at risk. Oil infrastructure has multi-decadal lifetime projections; thus, climate change and extreme weather events such as extreme temperatures, hurricanes, high winds, lightning strikes, storm surges, flooding, etc., pose an extra challenge to the oil supply chain, from upstream to downstream. In this paper, we review the climate change risk assessment frameworks, the impacts of climate change on oil infrastructure, and we identify gaps in the current knowledge, also suggesting future search directions on adapting the oil sector to climate change. The work overviews linkages between climate and oil industry design, operational, and service thresholds in a comprehensive hazard threshold matrix. Existing risk assessment methodologies that account for existing regulatory frameworks and interdependencies with other infrastructures are studied, leading to mitigation, adaptation, and sector resilience recommendations.
\end{abstract}

Keywords: oil; critical infrastructures; climate change; impacts; risks; vulnerability; critical event parameters

\section{Introduction}

The oil industry is a critical part of the global energy sector, as their processes have significant effects on all the productive sectors of the economy and the population. For many years, crude oil and oil products had the largest share in gross inland energy consumption, while they are still the principal energy source for electricity generation and the main source for thermal power [1,2].

According to the findings of the EU-CIRCLE project [3], climate change (CC) is anticipated to contribute to the faster aging and degradation of the oil infrastructure processes, from the oil extraction and upstream to the storage, refining and distribution processes, reducing lifecycle, service level, and leading to major disasters. Extreme temperatures, winds, hurricanes, droughts, flash flooding, storm surges, and forest fires are expecting to increase globally [4], with potentially severe off-site consequences through toxic-release, oil spillages, fire, or explosion scenarios (Natech accidents) [5-7]. Considering that CC is the second most critical factor that might increase the occurrence of a Natech event [8], actions should be taken to ensure the resilience of oil infrastructure, the investments in the oil industry, and the safety of people and the environment.

A holistic approach is, thus, required to make resilience-based informed decisions on the oil infrastructure growth and sustainability under extreme weather events (EWE) that are projected to be exacerbated under CC. Under those circumstances, the aim of this is to: 
1. introduce a state-of-the-art review of CC impacts to the oil industry, as well as, mitigation and adaptation measures;

2. identify the exposure -of the oil industry to EXE and assess the oil infrastructure's vulnerability to $\mathrm{CC}$, through the development of a hazard threshold matrix, based on a consistent approach for capturing the critical event parameters;

3. explore the oil sector's dependencies and interdependencies with other critical sectors;

4. set the basis for implementing an impact assessment framework for related studies;

5. provide recommendations for future research activities and industry uptakes

The paper explores all these challenges and difficulties and it is structured as follows: the proposed research methodology is presented in Section 2, including the literature review methodology and the resilience framework; CC assessment frameworks, the dependencies, and interdependencies of oil sector, the CC impacts on oil industry and possible adaptation measures are presented in Section 3; Identified gaps and recommendations for future work are presented in Section 4; Finally, the conclusions are discussed in Section 5.

\section{Research Methodology}

The proposed research methodology has been designed to provide valuable information to stakeholders for improving the resilience of the vulnerable oil sector to CC impacts. As the term resilience, encompasses the ability/capacity of any $\mathrm{CI}$ (or their network) to prevent, protect and prepare for CC impacts $[9,10]$, the accurate collection is a critical step to identify exposure, vulnerabilities, and impacts to the interconnected and interdependent CI of oil industry [11,12]. Any accurate vulnerability assessment requires a thorough analysis of existing literature review, design standards, and operational parameters of the climate impacts on the assets of the oil infrastructure [13,14]. As it is described further in Section 2.1, these weather-related thresholds can be found in literature and are values above or below a level, which the likelihood of a climate impact is considered sufficient to render the asset or operation exposed to severe damage and/or disruption of service critical operations (Table A1 of Appendix A [15]. Finally, Section 2.2 describes the elements of the resilient framework that includes the oil infrastructure taxonomy methodology, build on the development of an oil process-based analysis, based on the analysis of its constituent assets of the corresponding critical interconnected and interdependent processes within the oil sector. Also, it presents the climate hazards with the most critical impacts on the oil infrastructure and the suggested holistic methodological framework.

\subsection{Literature Review Methodology}

The data collection methodology uses a process-based (based on asset and critical services) approach to assess risk(s) caused by climate hazards, and identifies the related impacts on the oil industry processes and performance. To identify the impacts of EWE and CC in the oil industry, a systematic data collection based on scientific research, literature review of reports (scientific journals articles, theses, government and non-governmental reports) related to different geographic locations globally was performed. This information was primarily studied to classify relevant information associated with extreme weather impacts and adaptation or mitigation measures in the context of oil infrastructure and its sectors and subsectors, dependencies, and interdependencies.

\subsection{Elements of the Oil Industry CC Resilience Framework}

\subsubsection{Overview of the Oil Sector Critical Services}

The oil industry's supply chain encompasses activities associated with the exploration, extraction, refining, transportation, and distribution of oil refined products across the world (from upstream to downstream as presented in Figure 1). The upstream sector involves the operations of crude oil extraction to the surface. The midstream sector includes the most common transportation modes 
(pipelines, rail, oil tanker and truck), storage, and wholesale marketing of crude or refined petroleum products. Finally, the downstream sector includes the oil refining processes along with the fuel distribution to the other $\mathrm{CI}$, retail and commercial customers, public services, etc.

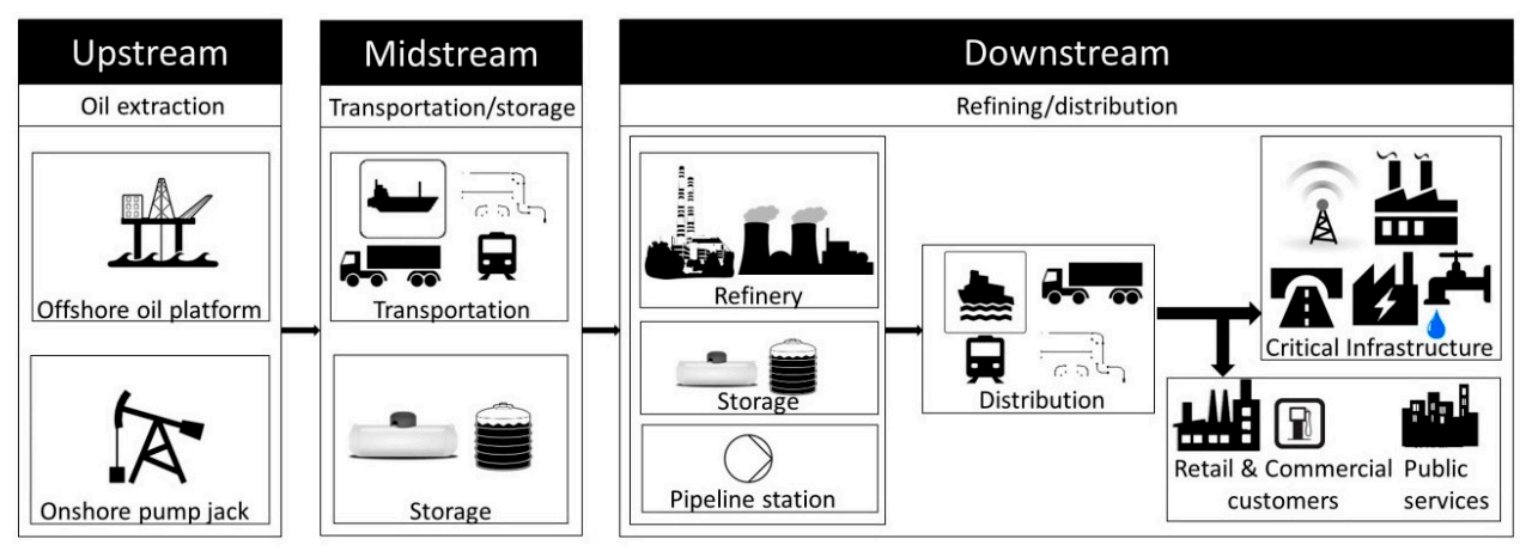

Figure 1. The oil supply chain, from upstream to downstream.

\subsubsection{Taxonomy of the Oil Infrastructure}

The analysis is based on the oil sectors' taxonomy based on the: (i) the critical services across the oil supply chain (Figure 1); (ii) the Department of Homeland Security Office of Infrastructure Protection (IP) implementation of the Infrastructure Data Taxonomy [16]; (iii) the European (EU) recommendations and guidelines included in the Directives 114/2008 [17,18] and (iv) the [19] Assessment Report (AR5) regarding the $\mathrm{CI}$ sectors analysis.

This study divides the oil sector into constituent critical services and assets from upstream to downstream, as presented in Table 1. The level of granularity applied has been defined based on a systematic analysis of existing literature review, design standards, and operational parameters of the climate impacts on the assets/critical processes of the oil infrastructure [13]. For example, in the oil sector, an oil refinery is considered as a critical service, which can be divided into its constituent processing assets/units, e.g., atmospheric distillation unit, fluid catalytic cracker, etc.

Table 1. Oil critical infrastructure sectors and subsectors.

\begin{tabular}{|c|c|c|c|}
\hline CI Sector & CI Subsectors & $\begin{array}{l}\text { Critical Services (Upstream- } \\
\text { Midstream-Downstream) }\end{array}$ & Assets \\
\hline $\begin{array}{c}\text { Energy (Oil, Gas, } \\
\text { Coal, Electricity, } \\
\text { Renewables) }\end{array}$ & Oil & $\begin{array}{ll}\text { - } & \text { Extraction } \\
\text { - } & \text { Transportation } \\
\text { - } & \text { Distribution } \\
\text { - } & \text { Refining/Processing } \\
\text { - } & \text { Storage }\end{array}$ & $\begin{array}{ll}\text { - } & \text { Offshore Drilling Units (drilling } \\
\text { - } & \text { Ships, jack-ups, etc.) } \\
\text { - } & \text { Onshore Drilling Rigs } \\
\text { - } & \text { Offshore Oil Wells } \\
\text { - } & \text { Offshore/Onshore Oil Pipelines } \\
\text { - } & \text { Oil Pumping Stations } \\
\text { - } & \text { Tanker vessels, Trucks, Rail Cars } \\
\text { - } & \text { Port } \\
\text { - } & \text { Oil Storage Facilities } \\
\text { - } & \text { Marine Terminals } \\
\text { - } & \text { Oil Refineries } \\
\text { - } & \text { Cooling system } \\
\text { - } & \text { Refined Products Storage } \\
\text { - } & \text { Storage tanks } \\
\text { - } & \text { Buildings } \\
\text { - } & \text { Employees }\end{array}$ \\
\hline
\end{tabular}




\subsubsection{Climate Hazards}

The climate hazards that are considered in this study are introduced in Table 2. These are used to provide an estimation of the likelihood of the climate-induced risks to infrastructures and contribute to the identification of the operational or structural thresholds. They have been divided into two separate categories: (a) the climate drivers, which are the direct outcome either from observational data, or from different models, and (b) to climate hazards, which are a direct consequence of climate drivers. In this study, extreme winds and hurricanes and storm surges/waves are discussed together due to the commonality of their impacts.

Table 2. Climate parameters.

\begin{tabular}{ll}
\hline Climate Drivers & Climate Hazards \\
\hline Temperatures & Flash flooding \\
Precipitation (rain/snowfall)_humidity & Forest Fires \\
High winds/Hurricanes & Drought \\
Lightning strikes & Earth movement (caused by climate drivers such as \\
Sea level rise & rain landslide, erosion, avalanches) \\
Strom surges, waves & \\
\hline
\end{tabular}

\subsubsection{Impacts and Vulnerability}

This study addresses the following impacts of climate hazards in Section 3.3, as shown in Table 5:

- direct impacts on the main processes of the oil infrastructure (loss of functionality, service, and operations)

- loss of infrastructure (e.g., destruction failures)

- cascading effects from other CI sectors such as electricity/transport/water that affect the integrity and operations of oil assets

- changes in the provision of "services and products" to the society such as demand and consumption patterns

- indirect impacts (including externalities such as societal costs)

\subsubsection{Risk and Adaptation Assessment Framework}

The identification of climate-related risks is made, taking into account the asset design thresholds and asset interconnections, the direct and indirect climate impacts as presented schematically in Figure 2. These could form the basis for risk-informed decisions on climate change adaptation of the oil industry and improving infrastructure resilience [13]. 


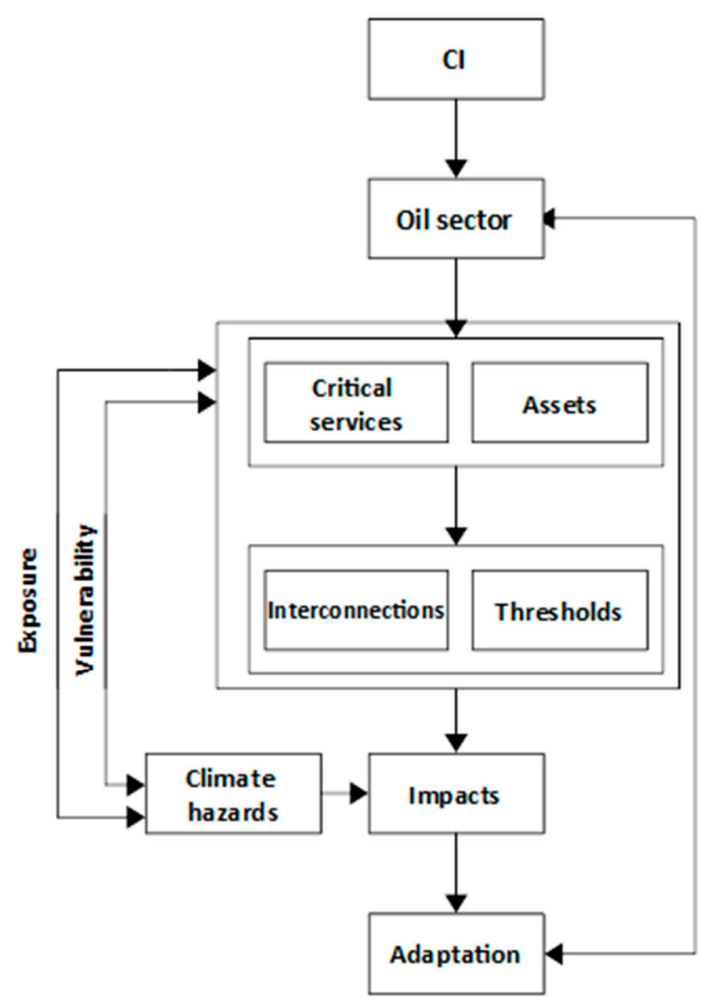

Figure 2. High level description of the oil sector adaptation and the performed analysis under the scope of this paper.

\section{Analysis of CC Risks to Oil CI}

The literature review includes (i) CC risk assessment methodologies; (ii) dependencies and their interdependencies with other sectors, and domino effects; (iii) CC impacts to the oil sector assets and processes assets and processes; and (iv) CC adaptation solutions and resilience frameworks.

\subsection{Literature Review of CC Risk Assessment Frameworks}

Nowadays, the oil industry has gradually shown a strong commitment to sustainable and resilient development, by introducing extreme weather events into broad risk management frameworks [20-24]. The majority of processes and facilities have been designed to withstand CC risks, but extreme events may exceed design and operational thresholds. Many scientists have already emphasized the prospective for climate hazards to trigger chemical accidents leading to releases of toxic, flammable, and explosive materials [25-30]. The combination of increasing complex industrial designs and the anticipated increase in the frequency and intensity of the EWE due to CC [31] could lead to potentially more devastating Natech in the future.

The protection of the Oil industry is a significant component of national security for many countries and nations. The European Program on CI Protection [32] delivers a methodical, network-based strategy and for risk identification and mitigation following the "all-hazards" principle. The SEVESO directive (Directive 82/501/EEC) introduces a holistic risk management system (Directive 2012/18/EU), requiring industrial risk management plans regarding oil hazards prevention. Only individual actions have been implemented to oil or chemical industries where risk assessment methodologies have taken into consideration the impacts associated with the Natech events [33].

According to [34], Natech Risk Management addressing CC has already been implemented in six EU Countries (Bulgaria, France, Germany, Italy, Portugal, and Sweden [35-39]). In the UK, CIA's Responsible Care program [40] recommends that large complex industrial facilities subject to Control of Major Accident Hazards (COMAH) regulations should have emergency plans that include climate-related risks in their risk database. The UK addresses relevant risks on its national CC Risk 
Assessment and has made available a sector-specific guide for CC Adaptation Plans [40]. In Norway, plans and decisions adopted (in 2017) at various administrative levels accommodate the requirements implied by future CC by assessing climate-related risk factors and their significance for the Norwegian economy [41].

In parallel to national policies, EU has already funded several programs to develop CC risk assessment frameworks. The European Risk Assessment and Contingency Planning Methodologies for Interconnected Energy Networks addressed the protection and resilience of energy supply for European interconnected energy networks [42]. Also, a Risk and Vulnerability Analysis (RVA) method for critical infrastructures has been developed in the Risk and Decision Systems for Critical Infrastructures (DECRIS) project under the Research Programme on Societal Security and Safety (SAMRISK) using the "all-hazards" approach across sectors [43]. Last year, the pan European framework for strengthening Critical Infrastructure resilience to climate change (EU-CIRCLE) tested, in a case study, the risk assessment methodology on CI energy facilities of the primary energy hub of Cyprus, including oil transportation and storage and electricity production [44].

Across the U.S., many regions and sectors are already implementing climate risk management [45]. The U.S. Environmental Protection Agency (EPA) is committed to identifying and responding to the challenges that a changing climate poses to human health and the environment, as described in [46]. Several industry advocacy groups (such as the American Petroleum Institute (API), American Chemistry Council, National Association of Manufacturers, International Petroleum Industry Environmental Conservation Association (IPIECA), Oil and Gas Climate Initiative (OGCI), and the Climate Leadership Council) are working to advance climate proofing of the sector. In Canada, Northeastern British Columbia has performed an assessment of the region's future risks and opportunities, providing a starting point for integrating climate adaptation measures into planning, risk management, and decision-making throughout the dominant oil and gas sector [47].

Moreover major oil and gas companies study, develop, and utilize integrated CC risk management to identify, assess, characterize and manage climate-related risks as report [48] mentions. The acclimatize report in [49] describes that a company's business strategies, its future objectives, and plans are the starting point for any risk assessment of the impact of CC, in order to support the development of an informed dialogue between institutional investors, companies, and policy-makers about the direct and indirect impacts of a changing climate on key business sectors. IPIECA through its report "Addressing adaptation in the oil and gas industry" [50], made an effort to examine oil and gas industry awareness of CC-related risks and identify suitable responses and ways in which these responses are being integrated into broad risk management frameworks. The Australian National University [51] in 2013, has provided evidence to help investors assess and integrate climate risk and opportunity in the oil and gas sector into investment analysis. Several companies are currently using the climate-related financial disclosures $[52,53]$. The stakeholder engagement approach is followed by five major oil and gas companies to tackle related physical risks from sea-level rise, and enhanced storm surges on the continental U.S. [54,55].

\subsection{Oil Sector's Dependencies and Interdependencies with Other Critical Sectors}

The starting principle behind this section is that "A CC risk assessment that does not take into serious consideration $\mathrm{CI}$ dependencies and interconnections could underestimate and devaluate risks" [56]. Apparently, the increasingly dependent, interdependent, and interconnected nature of CI exposes previously unseen risks, new vulnerabilities, and opportunities for disruption across the $\mathrm{CI}$ networks $[57,58]$. In consonance with EU-CIRCLE approach in the registry of assets, a dependency is a uni-directional connection among two assets belonging to the same or other infrastructure (sub)sectors, through which the ability of one infrastructure to provide a service is dependent on the operation of the other infrastructure but not vice versa.

Extreme winds can damage overhead power lines and lead to loss of power supply on oil refineries, which might result in delay or disruption of the oil processing, resulting in a cascading failure [58]. 
A flash flooding event might affect refineries' oil production, leading to delays or interruption of the fuel supply, which could be used in electricity infrastructure for generation, causing a shortage of electricity production in the area. A lack of electric power is still able to impact supplementary other CI serviced by the utility, creating domino effects, with economic, societal, or political disturbances in a broad area [59].

During storms, either pumping systems and compressor stations operations, or electricity and telecommunications networks (ICT) can be totally out of service, as flooding events can drive to power losses [60,61]. For example, hurricane Katrina caused pipeline closures as a consequence of power loss, while additionally, power failures in the electricity and ICT networks caused the shutdown of ports, railroads, refineries, and pipeline stations that were not physically impacted through the hurricane [60]. As presented in Figure 3 and Table 3, the oil industry is largely dependent on the transportation and distribution of crude oil, natural gas, electric power, water, telecommunication, industry, etc. [62], whilst also the above-mentioned sectors are highly dependent on the oil sector (Table 4). All transportation sector modes, such as rail, oil tankers, vessels, shipping containers, up to gasoline supply stations, and trucks are virtually used for the transportation and distribution of the oil and refined products. Thus, interruptions and delays to the whole supply chain might are likely due to EWE.

In the past, extreme hydro-meteorological events have damaged extensive parts of roads, bridges, and rail crossings, leading to road and spillage accidents with releases of polluting elements in the environment. The transportation sector is also heavily dependent on oil products; as a matter of fact, the highest dependency of all sectors [2], with a percentage of $93.8 \%$ usability of oil and refined products, as compared to the $41.7 \%$ and $10.0 \%$ for the energy and industrial sectors, respectively. The oil demand of the transportation sector globally is in the range of 11 billion liters per day (blpd) regarding gasoline, diesel, heavy fuel oil, and jet fuel [63], while Eurostat Energy Balances of 2014 comments that industry sector demands more or less $20.0 \%$ of oil supplied to EU markets. In spite of the declining production and consumption in Europe (EU), crude oil remains the largest contributor to the energy generation industry-it meets the global demand in the range of $60.0 \%$ [3]. The industry sector (including chemical infrastructure) consumes around 0.6 billion toes $(\sim 15.0 \%)$ of refined petroleum products as raw material input for production and manufacturing purposes [64].

\section{The interdependence of Oil infrastructure to other $\mathrm{Cl}$}

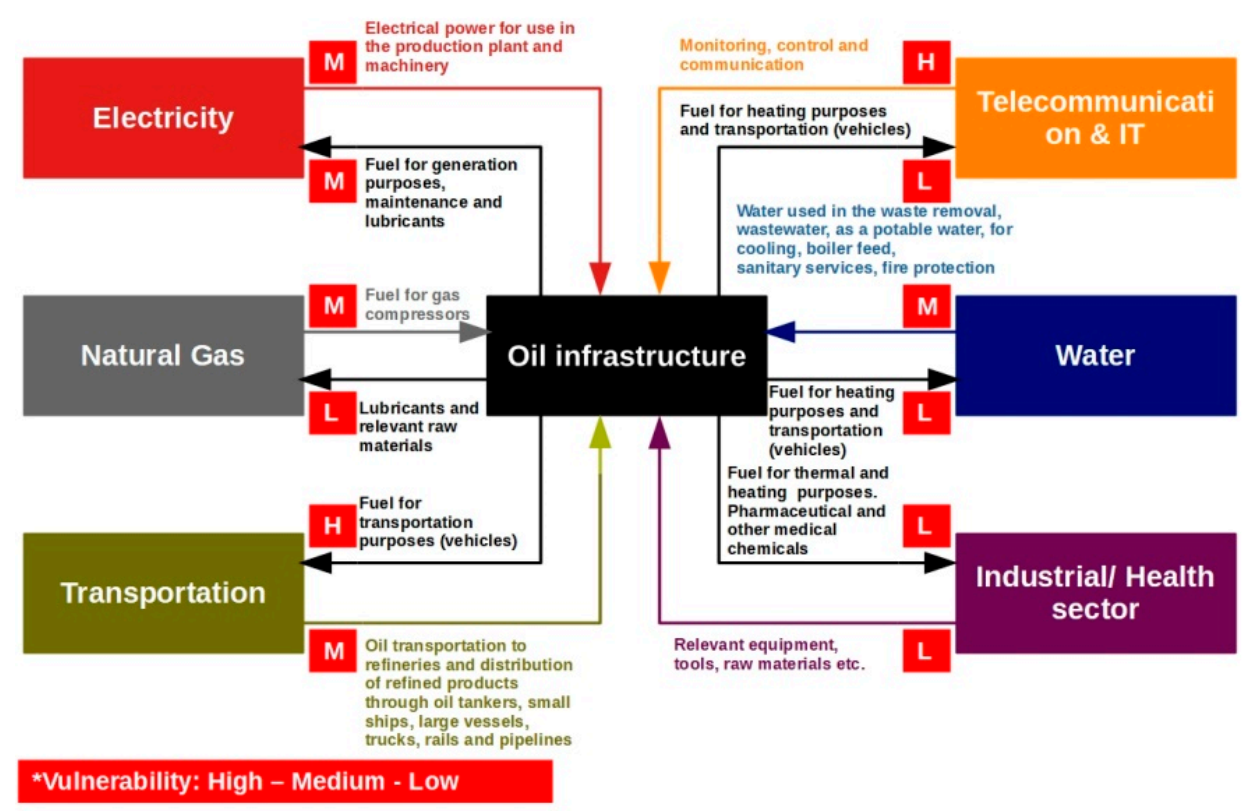

Figure 3. The interdependence of the oil infrastructure. Source: adapted from [65]. 
The oil sector is highly dependent on electrical power and electricity networks. For example, in U.S. the purchased electricity consumed at refineries in an annual base is around 45-48 TWh in line with [66] (a refinery of around 30 million Mt per annum, consumes about 300 MW power). Despite the fact that oil industries meet their needs for electrical power through the use of their integrated combustion engines to generate electricity, a large amount of electricity is also provided by the electric and distribution utilities via the transportation and distribution grid, which is also exposed to EWE, as Table 3 describes. Quite the reverse oil is highly necessary for electricity production. Only in 2016, oil and gas accounted for $30.0 \%$ of total OECD gross electricity production, making the CI dependence on oil extremely high [67]. For instance, Malta, Cyprus, and Greece are the top three EU countries that rely profoundly on petroleum products, which account for $98.0 \%, 92.0 \%$, and $10.0 \%$ of consumption [68]. Table 4 indicates the most critical issues that the interdependent electricity sector should address due to the CC impacts on oil refining and transportation processes.

Moreover, oil refineries use quite large volumes of water, mainly for their cooling system. Despite the fact that oil industry water needs are through a self-running network and sea or river water, there is a still great need for water surplus. Indeed, the water sector provides potable water through the drinking water network, wastewater, or even flood water network. As energy and water are connected, the production of energy requires a significant amount of water, and in turn, the extraction, treatment, distribution, and use of water together with wastewater treatment necessitate a huge amount of energy [69]. Results of [70] presented that oil refinery water consumption was 0.34 and 0.47 (L water/L crude) for cracking and heavy coking processes, while gasoline needs the largest amount of water, around $0.60-0.71 \mathrm{~L}$ water/L gasoline to be produced. Smaller amounts of water are needed for boiler feed, processing, sanitary services, and fire protection. Literature (Table 4) so far indicates that the cooling water quality and quantity might be affected by the extreme temperatures, while above-ground infrastructure such as valves, pumping stations, and pipelines are the most exposed assets to precipitation events, floods and landslides, making oil industry vulnerable to water infrastructure damages. Contrariwise, a technology from the Information and communications technology (ICT) sector (e.g., telecommunication, industrial automated technology and equipment, monitoring systems), is critical in the processes/operations within the oil sector supply chain.

Based on the literature findings, the dependency of oil infrastructure to transportation and ICT sectors is the highest, while interdependencies to electricity, natural gas, and the water sector are considered to be medium (Figure 3, Tables 3 and 4). 
Table 3. Oil industry dependency on other types of Critical infrastructure.

\begin{tabular}{|c|c|c|c|c|c|}
\hline Climate Parameter & $\begin{array}{c}\text { Primary } \\
\text { Affected Sector }\end{array}$ & $\begin{array}{c}\text { Secondary } \\
\text { Affected Sector }\end{array}$ & Process & Impact & Sources \\
\hline \multirow{3}{*}{ Temperatures } & Transportation & \multirow{3}{*}{ Oil sector } & \multirow{3}{*}{ All processes } & - Damages to the oil supporting transportation infrastructure & {$[71,72]$} \\
\hline & Electricity & & & $\begin{array}{l}\text { - Fuel supply delays or interruptions } \\
\text { - Increased cooling or load needs }\end{array}$ & [73-75] \\
\hline & Transportation & & & - Increased maintenances, transportation and distribution costs & {$[40,76]$} \\
\hline $\begin{array}{l}\text { High winds/hurricanes/Precipitation } \\
\text { (rain/snowfall)-humidity/Flash } \\
\text { flooding/Sea level rise/Storm } \\
\text { surge/waves/Lightning/Forest fires }\end{array}$ & Electricity/ICT & Oil sector & All processes & $\begin{array}{l}\text { - Items thrown into the air by wind, or wind above the } \\
\text { structural threshold of a wooden pole, can impact distribution } \\
\text { electricity lines and lead to loss power supplies and } \\
\text { control systems } \\
\text { - Transmission lines, electrical equipment, substations, control } \\
\text { valves, and control stations can be damaged due to floods and } \\
\text { are able to cut off electricity provided to oil refineries } \\
\text { - Lightning strikes affect the electricity lines by both direct } \\
\text { (intercept with line conductors, towers or shielding wires) } \\
\text { and indirect effects (flashover on the electrical equipment on } \\
\text { the line) } \\
\text { - Also, smoke and ash deposition can ionize the air, creating an } \\
\text { electrical path away from the lines. This can shut down the } \\
\text { lines and produce power outages. }\end{array}$ & {$[40,55,77-81]$} \\
\hline $\begin{array}{c}\text { Temperatures/High } \\
\text { winds/hurricanes/Precipitation } \\
\text { (rain/snowfall)-humidity/Flash } \\
\text { flooding/Sea level rise/Storm } \\
\text { surge/waves/Drought }\end{array}$ & Water & Oil sector & All processes & $\begin{array}{l}\text { - The cooling water quality and quantity might be affected by } \\
\text { extreme temperatures. Also, water pipelines might freeze in } \\
\text { the pipe occurring expansion and cracking } \\
\text { Above ground infrastructure such as valves, pumping } \\
\text { stations, and river crossings are those of the most exposed } \\
\text { pipeline segments during a flood event } \\
\text { Drought, extreme precipitation, floods, sea level rise (SLR), } \\
\text { etc., can lead either to landslides or to erosion-scouring of } \\
\text { foundations and pipe supporting systems }\end{array}$ & {$[34,40,46,77,81-86]$} \\
\hline
\end{tabular}


Table 3. Cont

\begin{tabular}{|c|c|c|c|c|c|}
\hline Climate Parameter & $\begin{array}{c}\text { Primary } \\
\text { Affected Sector }\end{array}$ & $\begin{array}{c}\text { Secondary } \\
\text { Affected Sector }\end{array}$ & Process & Impact & Sources \\
\hline $\begin{array}{c}\text { Temperatures/High } \\
\text { winds/hurricanes/Precipitation } \\
\text { (rain/snowfall)-humidity/Flash } \\
\text { flooding/Sea level rise/Storm } \\
\text { surge/waves/Drought/Forest fires/ } \\
\text { Earth movement }\end{array}$ & Transportation & Oil sector & All processes & $\begin{array}{l}\text { - Extreme hot conditions might change the means of } \\
\text { transporting products due to the reduced sea ice covering the } \\
\text { Arctic sea } \\
\text { - Interruptions, delays, disruption of inspection, restoration } \\
\text { and accidents (from tanker trucks, vessels, shipping } \\
\text { containers, up to gasoline supply stations) might occur due to } \\
\text { hydro-meteorological events } \\
\text { - } \quad \text { Extreme winds can uproot trees and provoke damages to } \\
\text { unprotected electromechanical equipment, meters, occurring } \\
\text { interruptions and delays } \\
\text { Oil transportation by marine vessels might be liable to } \\
\text { hazards from flooding, and disruption of fuel delivery might } \\
\text { occur. Also, it can destroy roads, bridges, and rail crossings, } \\
\text { or generating landslides that could straight affect oil } \\
\text { transportation with releases of polluting elements } \\
\text { Landslides can cut off transportation networks, leading to } \\
\text { disruption of operations. Also, structural damages to } \\
\text { pipelines or other equipment integrity caused by weakened } \\
\text { soil structure might occur. }\end{array}$ & {$[47,77,79,87-95]$} \\
\hline $\begin{array}{c}\text { Temperatures/High } \\
\text { winds/hurricanes/Precipitation } \\
\text { (rain/snowfall)-humidity/Flash } \\
\text { flooding/Sea level rise/Storm } \\
\text { surge/waves/Drought/Forest fires/ } \\
\text { Earth movement }\end{array}$ & Industrial Sector & Oil sector & All processes & $\begin{array}{l}\text { - Delays or interruptions of relevant electromechanical } \\
\text { equipment, tools, raw and materials might occur }\end{array}$ & [77] \\
\hline $\begin{array}{l}\text { High winds/hurricanes/Precipitation } \\
\text { (rain/snowfall)-humidity/Flash } \\
\text { flooding/Sea level rise/Storm } \\
\text { surge/waves/Earth movement }\end{array}$ & Natural Gas & Oil sector & $\begin{array}{l}\text { Oil } \\
\text { refining/processing }\end{array}$ & $\begin{array}{l}\text { Interruptions in the fuel supply to the gas compressor might } \\
\text { occur, due to the exposed ground pipelines, valves, etc. }\end{array}$ & \\
\hline
\end{tabular}


Table 4. Critical infrastructures dependencies on the oil industry.

\begin{tabular}{|c|c|c|c|c|c|}
\hline Climate Parameter & Process & $\begin{array}{c}\text { Primary } \\
\text { Affected Sector }\end{array}$ & $\begin{array}{c}\text { Secondary } \\
\text { Affected Sector }\end{array}$ & Impact & Sources \\
\hline \multirow{3}{*}{ Temperatures } & Oil extraction & \multirow{3}{*}{ Oil sector } & Transportation & $\begin{array}{l}\text { Damages to the transportation } \\
\text { infrastructure }\end{array}$ & \multirow[b]{2}{*}[71,72]{} \\
\hline & $\begin{array}{l}\text { Oil refining/ } \\
\text { processing }\end{array}$ & & Electricity & $\begin{array}{l}\text { Fuel supply delays or } \\
\text { interruptions for generation } \\
\text { purposes, lubricants, etc. } \\
\text { Increased cooling or load needs }\end{array}$ & \\
\hline & $\begin{array}{c}\text { Oil } \\
\text { transportation/distribution }\end{array}$ & & Transportation & $\begin{array}{l}\text { Maintenance of the oil } \\
\text { transportation and distribution } \\
\text { sub-sector }\end{array}$ & \multirow[b]{2}{*}[40,76,77]{} \\
\hline $\begin{array}{l}\text { High winds/hurricanes/Precipitation } \\
\text { rain/snowfall)-humidity/Flash } \\
\text { flooding/Sea level rise/Storm } \\
\text { surge/waves/Lightning }\end{array}$ & All processes & Oil sector & $\begin{array}{c}\text { Electricity/ } \\
\text { Transportation/ } \\
\text { Industry/ICT/Water }\end{array}$ & $\begin{array}{l}\text { Fuel supply delays or } \\
\text { interruptions Delays and } \\
\text { interruptions of lubricants, raw } \\
\text { materials etc. }\end{array}$ & \\
\hline
\end{tabular}




\subsection{The CC Impacts to the Oil Industry}

The critical review of an already remarkable international research, shows evidence that oil sector is mostly exposed to hydrometeorological disasters (like flooding, hurricanes, storms, SLR, etc.), which can impact and disrupt the oil sector's vital processes, either the supply chain, or the oil sector's actual structure $[51,55,77,91,96-98]$, causing severe complications and many problems to the industry's ageing infrastructure (e.g., buildings, grounds, plants, machinery, and cooling system) [40]. More specifically, processes within the upstream critical service are highly vulnerable to EWEs, as described by literature $[51,55,77,91,96-98]$, while on the contrary, the oil downstream is exposed to EWE according to $[27,49,54,55,77,99-103]$ and midstream $[34,40,76,77,79,83-85,87-89,92-94,104-111]$. Table 5 presents an in-depth assessment of the impacts of CC on oil infrastructure with respect to the following CC projections. All these impacts were studied in relation to the CC impacts on oil infrastructure, and a summary is delivered for each of the critical processes in regard to the climate parameters.

Table 5. Overview of climate change impacts on oil infrastructure.

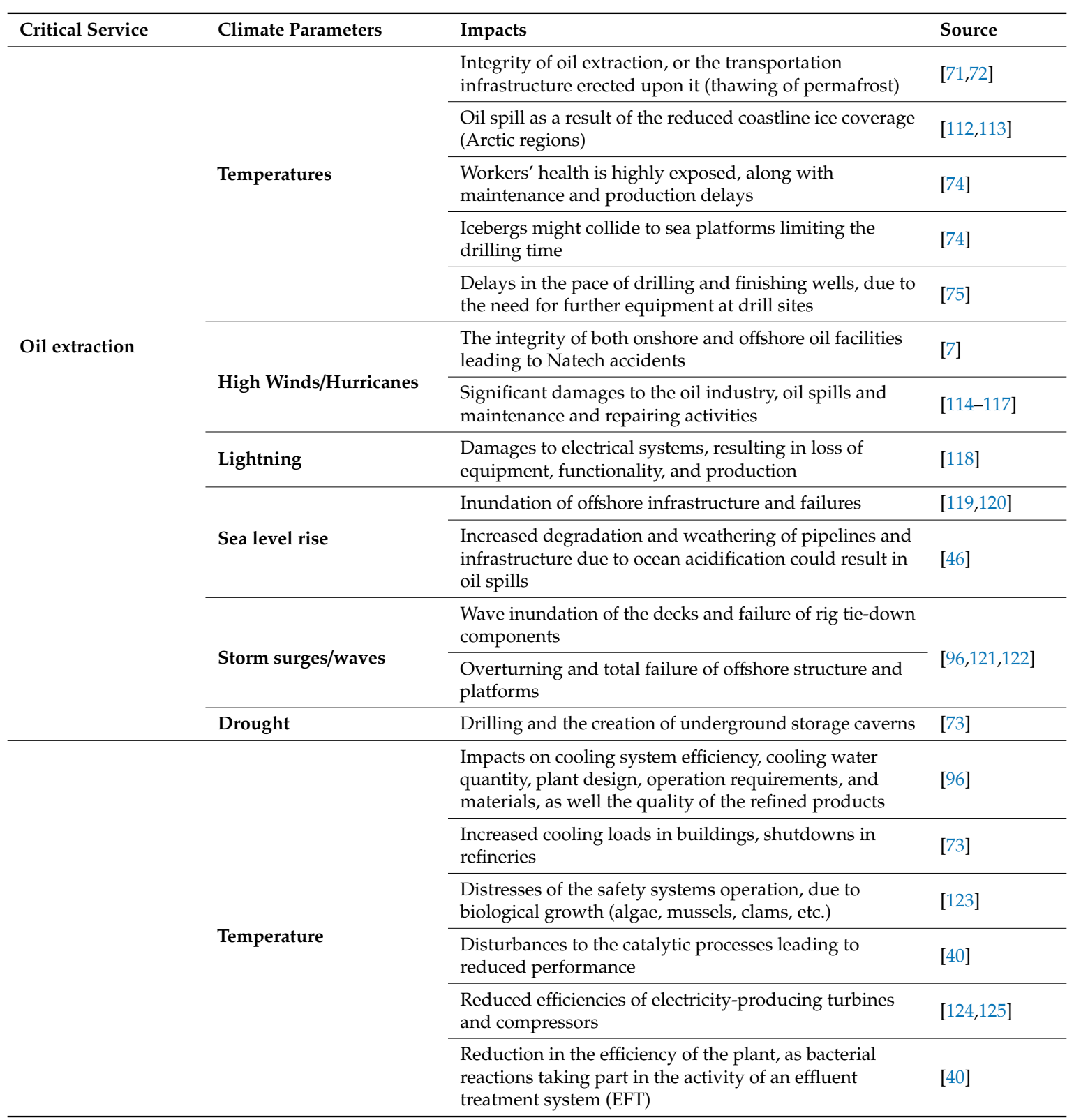


Table 5. Cont.

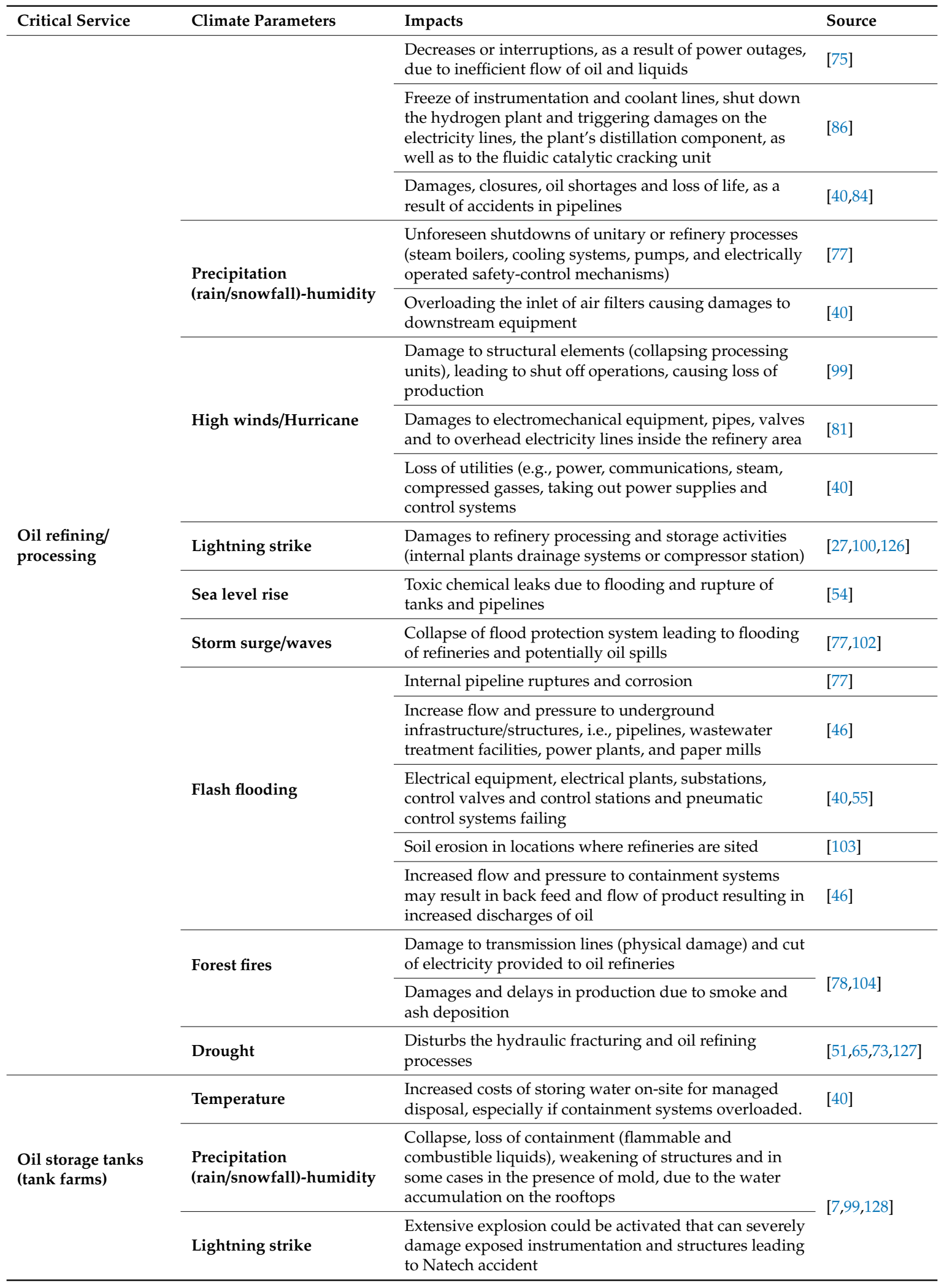


Table 5. Cont.

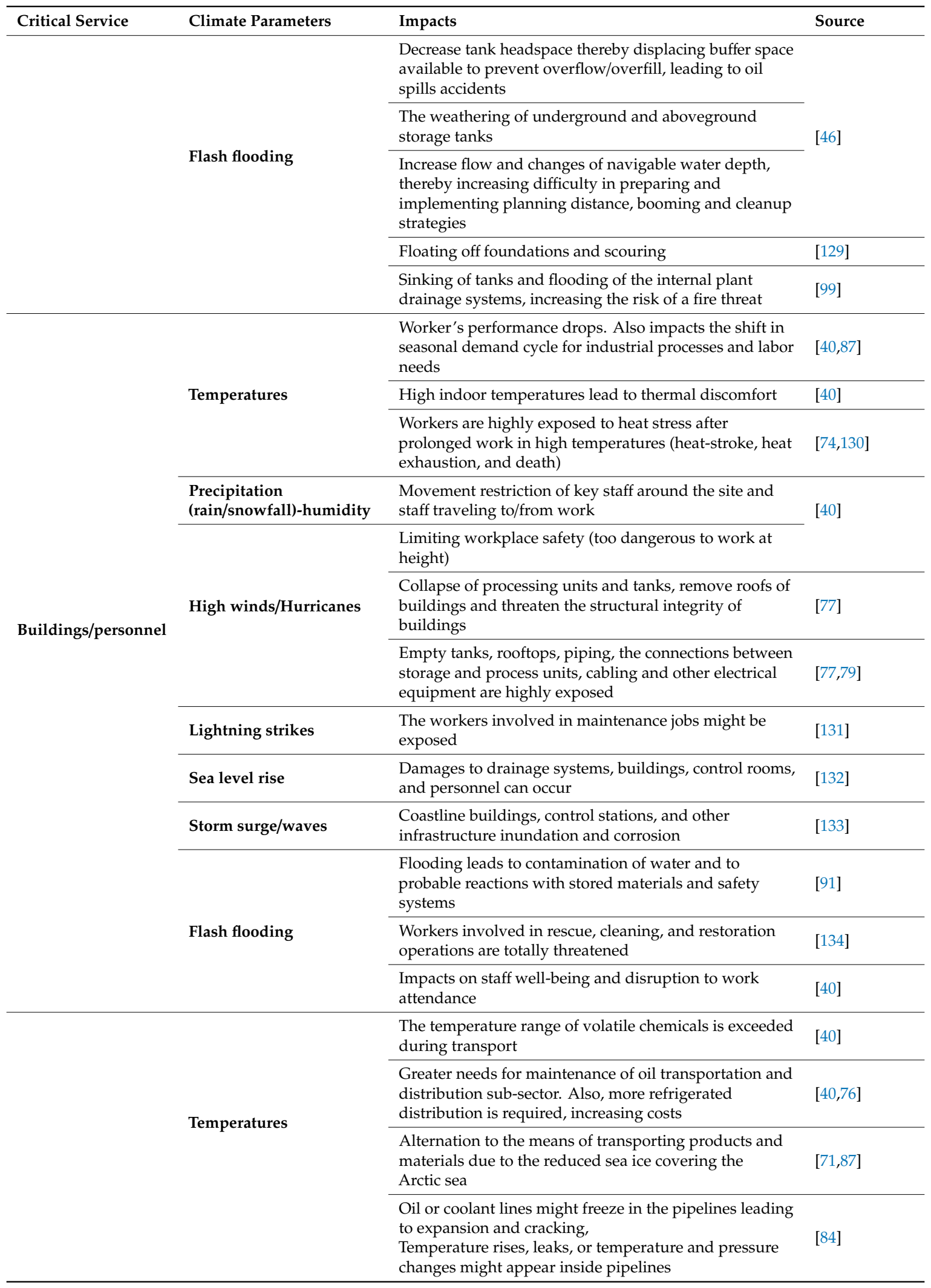


Table 5. Cont.

\begin{tabular}{|c|c|c|c|}
\hline Critical Service & Climate Parameters & Impacts & Source \\
\hline \multirow{13}{*}{$\begin{array}{l}\text { Oil transportation/ } \\
\text { distribution }\end{array}$} & \multirow{2}{*}{$\begin{array}{l}\text { Precipitation } \\
\text { (rain/snowfall)-humidity }\end{array}$} & $\begin{array}{l}\text { Interruptions, delays, disruption of inspection, restoration } \\
\text { and accidents might occur }\end{array}$ & [94] \\
\hline & & $\begin{array}{l}\text { Electrical damages to equipment might also occur, } \\
\text { preventing the normal port operations, also interrupting } \\
\text { shipping or other industrial operations, increasing the risk } \\
\text { of collisions. }\end{array}$ & {$[135]$} \\
\hline & High winds/Hurricanes & $\begin{array}{l}\text { Interruptions and delays to the whole delivery and } \\
\text { distribution system (from tanker trucks, vessels, shipping } \\
\text { containers, up to gasoline supply stations) }\end{array}$ & [88-92] \\
\hline & & $\begin{array}{l}\text { Extreme winds can uproot trees and provoke damages to } \\
\text { unprotected electromechanical equipment, meters, } \\
\text { occurring interruptions and delays }\end{array}$ & [79] \\
\hline & Sea level rise & $\begin{array}{l}\text { Pipelines' exposure to sea or river water, might lead to } \\
\text { corrosion of underground pipes as a consequence of } \\
\text { saltwater intrusion of groundwater }\end{array}$ & {$[85,135]$} \\
\hline & \multirow{3}{*}{ Storm surges/waves } & $\begin{array}{l}\text { Displacing covers and spans, in the way of uncovering and } \\
\text { exposing the pipeline (either by causing vertical } \\
\text { displacement or rupture or by destabilizing the sand or silt } \\
\text { above the underground offshore tubes) }\end{array}$ & {$[92,107,135]$} \\
\hline & & $\begin{array}{l}\text { Interruptions to oil transportation (by vessels, boat handling, } \\
\text { ferry docking, barge) }\end{array}$ & [108-110] \\
\hline & & $\begin{array}{l}\text { Irregular increase in the water levels of canals, lakes, and } \\
\text { rivers, affecting the supply of crude oil and of raw materials }\end{array}$ & [77] \\
\hline & \multirow[t]{2}{*}{ Flash flooding } & $\begin{array}{l}\text { Damages to the above-ground infrastructure such as valves, } \\
\text { pumping stations, and river crossings. Sensors installed in } \\
\text { the interior of pipelines might failure causing several issues } \\
\text { and leaks to the pipeline systems }\end{array}$ & {$[77,81,82]$} \\
\hline & & $\begin{array}{l}\text { Oil transportation by marine vessels might be liable to } \\
\text { hazards, and disruption of fuel delivery might occur. Roads, } \\
\text { bridges, and rail crossings can also be destroyed. Also, } \\
\text { landslides might be triggered that could straight affect oil } \\
\text { transportation with releases of polluting elements }\end{array}$ & [77] \\
\hline & \multirow{2}{*}{ Drought } & $\begin{array}{l}\text { Disruptions, delays, and stoppages in petroleum delivery } \\
\text { might occur, reducing, for instance, the cargo limits for } \\
\text { shipping }\end{array}$ & {$[73,111]$} \\
\hline & & $\begin{array}{l}\text { Lead to landslides, or to erosion-scouring of foundations } \\
\text { and pipe support systems }\end{array}$ & [40] \\
\hline & $\begin{array}{l}\text { Earth movement due to } \\
\text { heavy rains }\end{array}$ & $\begin{array}{l}\text { Cut off transportation networks, leading to disruption of } \\
\text { operations, causing loss of containment, and increasing } \\
\text { maintenance and pollution costs }\end{array}$ & {$[47,136]$} \\
\hline
\end{tabular}

\subsection{Adaptation Measures}

For over two decades, the oil industry has been concerned about CC impacts; its attention has been mainly focused on mitigation plans regarding GHG emissions reductions [137] and not implementing serious actions in terms of an adaptation policy. Only a handful of oil and gas companies developed comprehensive, corporate-wide CC adaptation strategies [51], including EXE and CC impacts to the oil sector explicitly [50]. The Paris agreement [138], introduced a way to kick off the implementation and integration of adaptation measures to national strategies in between member states. Given the above, 
adaptation policy is referred to as the establishment of a detailed program of activities at the country level with the aim to address the consequences of CC. It is expected to support the establishment of climate-resilient infrastructure by ensuring that an asset is located, designed, built and operated with both the current, and future climate in mind and incorporates resilience to the impacts of CC over the lifetime of that asset [139].

As highlighted above, there is little guidance available on how CC impacts and Natechs should be prepared for or avoided, as this is a relatively new field of study [140]. Table 6 presents an updated review of the most recognized structural and non-structural prevention and mitigation measures to reduce potential CC damage and losses to the oil sector.

Table 6. Prevention and mitigation measures to address climate change to oil industry.

\begin{tabular}{|c|c|c|c|}
\hline Critical Service & Climate Parameters & Adaptation Measures & Source \\
\hline \multirow{7}{*}{ Oil extraction } & Temperature & $\begin{array}{l}\text { Heating systems for water systems hydraulic fracturing at } \\
\text { drill sites to prevent frost }\end{array}$ & [75] \\
\hline & \multirow[t]{2}{*}{ High winds/Hurricanes } & $\begin{array}{l}\text { Review design thresholds of offshore structures } \\
\text { considering CC }\end{array}$ & [141] \\
\hline & & $\begin{array}{l}\text { Upgrading oil platforms, the rigs and the number of } \\
\text { anchors) to make it more resilient to hurricanes }\end{array}$ & $\begin{array}{l}{[51,99,} \\
142]\end{array}$ \\
\hline & Lightning strikes & $\begin{array}{l}\text { Offshore drilling companies should invest in lightning } \\
\text { protection for offshore drilling }\end{array}$ & [143] \\
\hline & Sea level rise & Raising of the decks of offshore platforms & {$[119,120]$} \\
\hline & \multirow[t]{2}{*}{ Storm surges/Waves } & $\begin{array}{l}\text { Plan and training (including exercises) for the evacuation } \\
\text { of personnel }\end{array}$ & \multirow[t]{2}{*}[144,145]{} \\
\hline & & Increasing the height of the platform & \\
\hline \multirow{10}{*}{$\begin{array}{l}\text { Oil processing/ } \\
\text { refining }\end{array}$} & High Winds/Hurricanes & $\begin{array}{l}\text { Review of the design of installations located in the } \\
\text { coastline. Filling of empty tanks to avoid floating or wind } \\
\text { buckling of the shell, tying down of components to reduce } \\
\text { the risk of missile creation during high winds, or the } \\
\text { special protection or relocation of safety-critical systems to } \\
\text { avoid wave loading and water intrusion }\end{array}$ & [77] \\
\hline & Lightning strikes & $\begin{array}{l}\text { More research into the dynamics of lightning impact on } \\
\text { equipment is required }\end{array}$ & \\
\hline & Storm surges/waves & $\begin{array}{l}\text { Safe protection and relocation of crucial components and } \\
\text { to build concrete walls and dikes }\end{array}$ & [146] \\
\hline & \multirow{6}{*}{ Flash flooding } & $\begin{array}{l}\text { (i) Position new facilities considering CC and risks of } \\
\text { flooding; (ii) Flood and coastal erosion management } \\
\text { strategies for existing facilities; (iii) Flood defense } \\
\text { measures; (iv) Improve drainage systems }\end{array}$ & {$[49,51]$} \\
\hline & & $\begin{array}{l}\text { Waterproofing of equipment and buildings, securing of } \\
\text { equipment (e.g., anchoring storage tanks, restraining gas } \\
\text { cylinders), and adequate emergency-response and } \\
\text { contingency planning to help minimize downtimes. }\end{array}$ & \\
\hline & & $\begin{array}{l}\text { (i) flood protection and adaptation measures, including } \\
\text { the reassessment of flood-prone zones; (ii) avoiding } \\
\text { building in flood-prone areas where possible; (iii) } \\
\text { adoption of slowing, steering, and blocking water } \\
\text { techniques; (v) elevation of buildings or building } \\
\text { components above the 100-year flood contour level }\end{array}$ & [77] \\
\hline & & Development of alarm safety flood systems & [146] \\
\hline & & Increase storage capacity for vital equipment and supplies & \multirow[b]{2}{*}[49,51]{} \\
\hline & & $\begin{array}{l}\text { (i) Removal of solid salt to approved landfill; (ii) Brine } \\
\text { injection; (iii) Ocean outfall; (iv) Treatment of salt to enable } \\
\text { it to be used as table salt or other commercial uses }\end{array}$ & \\
\hline & Drought & $\begin{array}{l}\text { (i) Explore and invest in the development of substitute } \\
\text { water supplies; (ii) collecting stormwater and floodwaters; } \\
\text { (iii) more efficient use of water; (iv) water treatment and } \\
\text { recycling }\end{array}$ & {$[49,51]$} \\
\hline
\end{tabular}


Table 6. Cont.

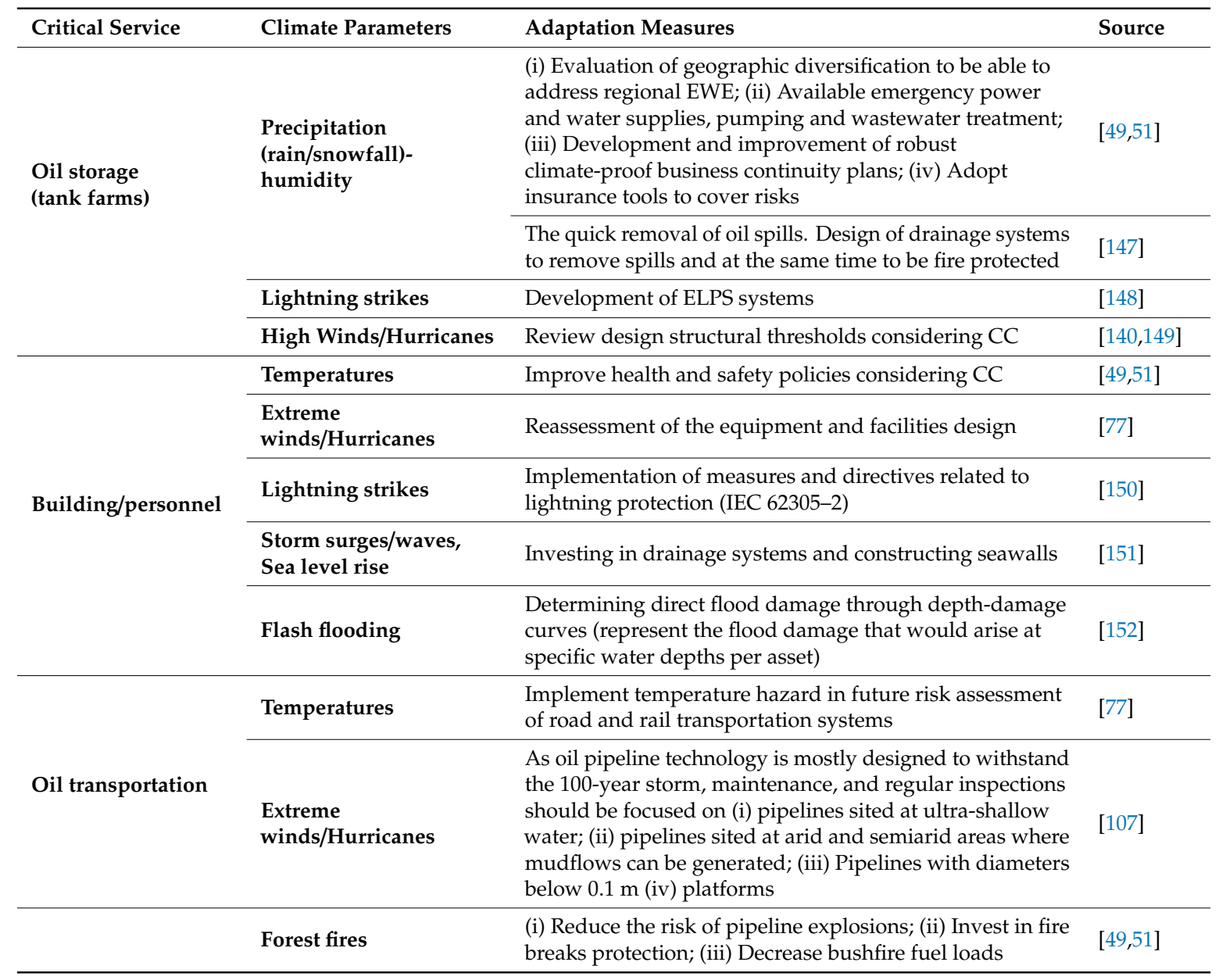

\section{Recommendations for Industry Uptakes}

The work has performed an extensive overview of the main elements of how CC is anticipated to impact the oil industry and detailed efforts on how to adapt to emerging challenges. The effective and efficient response to $\mathrm{CC}$ related challenges require coherent activities on behalf of the oil industry that: (a) encompasses the facility, the built environment, including their assets, the community, and the emergency response-capacity and resources [77]; (b) builds on future projections and identified risk through-out the facility lifetime; and (c) engages in risk-informed decisions including long term planning and preparedness under deep uncertainties.

As a conclusion to this work, we recommend the following domains that would help the industry to enhance the oil sector resilience:

1. A shift from risk to resilience informed decision making under CC, considering Natech accidents

Innovative and comprehensive risk assessments are needed that include CC, based on data-driven approaches that allow a CI operator to assess risks, accurately identify and decrease vulnerabilities, improve resilience and diminish potential climate impacts [153], also addressing oil infrastructures' interconnections. CC should also be considered as an important Natech triggering mechanism in Quantitative Risk Assessment (QRA), which is mandatory for the oil industry. Also, it is highly recommended to introduce the element of "resilience-by-design" when assessing the potential impacts of newly planned infrastructures to climate pressures and future time horizons. 
2. Enhance the oil sector resilience capacities

The resilience of the oil sector should be quantified holistically based on the existing capacities of the sector, following the comprehensive approach of the EU-CIRCLE project:

- Anticipatory capacity, linked to a better understanding of risks at different temporal and spatial scales, early warning systems, and making risk and emergency.

- Absorptive capacity, linked to increasing defenses and reducing vulnerabilities accounting for structural, technology, processes and operational domains

- Coping capacity, linked to enhancing cooperation and mounting effective response within- and across- organizational boundaries during crises

- Restorative capacity linked to faster business recovery

- Adaptive capacity linked to augmenting the sector's potential to adapt to emerging threats and challenges and be able to invest in new capabilities (e.g., through research)

\section{Support adaptive processes of the oil sector}

Climate risk management and implementation of adaptation actions will require increasing internal capability, as well as enhancing the knowledge base of management personnel, design engineers, and contractors. In addition, it may also require significant capital investments (for example, plant modifications), particularly in the longer term, and also efforts to identify and evaluate risks, develop strategies to mitigate and manage risks, and subsequently, to implement these strategies [50]. Changes in the hazards' frequency of appearance, magnitude, intensity, speed of event should be exhaustively estimated when assessing the impact of CC. Hazards evolving at a faster pace will require new capabilities to anticipate, such as early warning systems, and efficient responders' placement and also faster deployment and establishing collaboration between stakeholders. More intense hazards could lead to higher vulnerabilities and potentially increased damages to the operational capacity of CI.

4. Tools to process climate data and extremes

CC may lead to the re-design or enhancing of CI assets defenses. It is recommended to perform these, based on the micro-scale climate characteristics rather than relying on large scale global simulations. Work on identifying new relevant and reliable indicators related to the specific characteristics of $\mathrm{CI}$, even on a local scale, should be actively pursued in the context of climate services. Think "out of the box" when considering which hazards could be of relevance to CC risk assessment. The use of "synthetic hazards" to stress-test CI capacities is highly recommended, as global/regional climate models are not yet capable of capturing several high-end phenomena (e.g., tornadoes, waterspouts, and lightning) which are considered outside of the capabilities of present Global and Regional Climate Models.

5. Increase knowledge on impact chains, including interconnections and interdependencies

Given the complex and interconnected nature of the oil sector, a more comprehensive risk assessment and analysis framework are needed in order to capture the full range of future potentially disruptive scenarios, adequately. Future work should concentrate on the development of a universal framework in order to deliver concrete understanding and assessment of oil sector dependencies, interdependencies, and cascading effects, thus contributing to the effective determination of oil industry CC. The vulnerability of CI to CC is a multi-dimensional process and should account for (a) physical/structural damages due to extreme events, (b), the operational element of CI, including changes to supply and demand profiles, (c) the impact to society, which should not be neglected. 
6. Engage in scientific/climate community and industry stakeholders

It is recommended that the oil sector takes a leading role in establishing local/regional/thematic forums to expand the knowledge base for CC studies. This requires the development of dedicated methodologies and tools, as well as guidance for operators and authorities on how to consider climate hazards in industrial risk assessments [77]. Also, it requires further understanding of how CC will impact the oil industry and how these impacts can affect other CIs [154-156]. It would be highly beneficial if scientists and engineers worked closely with industry and policy-makers in an interdisciplinary effort to effectively tackle the problem of Natech risk reduction. In this regard, public-private partnerships could play a key role in linking science, practice, and policy-making [34, 157,158]. Finally, it is worth remembering that CC is not only about negative impacts, but rather one of the many challenges that $\mathrm{CI}$ owners/operators must address when preparing for a sustainable future. EU-CIRCLE project's key recommendation is that Resilience based Adaptation could provide a sustainable modus operandi linking CC Adaptation and Disaster Risk Reduction, and this process should engage CI operators, national authorities, and scientists.

\section{Conclusions}

This work provided a comprehensive overview of the potential impacts of CC and related hazards on the oil industry, assessing the potential to substantially affect the lifespan, service level leading to significant damages to the facilities and operations of the oil industry. The study identified how climate parameters impact oil CI, assessed vulnerabilities of assets and services, and discussed the direct dependencies and interdependencies to other critical sectors. These set the underlying framework for conducting CC risk assessments and presenting mitigation and adaptation measures. This study attempted to quantify the CC impacts on oil infrastructure and to detect the most vulnerable areas for future investigation.

The present work presented a review of how CC is expected to affect the oil industry considering multiple impacts and hazards. A holistic approach has been selected that includes: (i) direct impacts to the main processes of the oil infrastructure (loss of functionality, service, and operations); (ii) loss of infrastructure (e.g., destruction failures); (iii) cascading effects from other CI sectors such as electricity/transport/water that affect integrity and operations of oil industry; (iv) changes in the provision of "services and products" to the society such as demand and consumption patterns; (v) indirect impacts (including externalities such as the societal costs). This study can be considered as a starting point for climatologists, researchers, and practitioners alike to perform CC risk assessment studies and facilitate cooperation.

Funding: This research received no external funding.

Acknowledgments: Authors acknowledge partial support by the European Union's Horizon 2020 research and innovation program under the grant agreement $n^{\circ} 653824 / E U-C I R C L E$.

Conflicts of Interest: The authors declare no conflict of interest. The funders had no role in the design of the study; in the collection, analyses, or interpretation of data; in the writing of the manuscript, or in the decision to publish the results. 


\section{Appendix A}

Table A1. Oil sector assets and critical services vulnerability to CC.

\begin{tabular}{|c|c|c|c|c|}
\hline Hazard & Type of Asset/Per-Process & $\begin{array}{l}\text { Vulnerability } \\
\text { (H/M/L) }\end{array}$ & Threshold & Source \\
\hline \multirow{5}{*}{$\begin{array}{l}\text { Temperatures } \\
\text { (Hot) }\end{array}$} & $\begin{array}{l}\text { Refinery vacuum system } \\
\text { and fractionation plant } \\
\text { crystallizers cooling } \\
\text { systems }\end{array}$ & Medium & $\begin{array}{l}32{ }^{\circ} \mathrm{C} \text { is the maximum } \\
\text { designed cooling water } \\
\text { temperature }\end{array}$ & [159] \\
\hline & \multirow[b]{2}{*}{ Thermal plant } & \multirow[b]{2}{*}{ Small } & $\begin{array}{l}\text { Loss of capacity by } 1.0-20 \% \\
\text { for each } 1{ }^{\circ} \mathrm{C} \text { higher than } 20^{\circ} \mathrm{C}\end{array}$ & {$[124,125]$} \\
\hline & & & $\begin{array}{l}\text { Maximum water temperature } \\
\text { at discharge should be } 30^{\circ} \mathrm{C} \text {. }\end{array}$ & [160] \\
\hline & Personnel & $(* *)$ & $\begin{array}{l}\text { Heat index from } 32^{\circ} \mathrm{C} \text { to } \\
39^{\circ} \mathrm{C} \text { can lead to moderate } \\
\text { risk, while heat index higher } \\
\text { than } 46^{\circ} \mathrm{C} \text { cause extreme risk } \\
\text { to employees safety }\end{array}$ & {$[161,162]$} \\
\hline & Oil demand & Medium & $\begin{array}{l}\text { Reduced oil demand by } \\
12.0 \% \text { per } 1{ }^{\circ} \mathrm{C} \text { increase }\end{array}$ & [71] \\
\hline \multirow{6}{*}{$\begin{array}{l}\text { Temperatures } \\
\text { (Cold) }\end{array}$} & $\begin{array}{l}\text { Oil pipelines damages (oil } \\
\text { transportation and } \\
\text { distribution might be } \\
\text { interrupted \& delayed) }\end{array}$ & High & $\begin{array}{l}\text { Arctic coast had shown a } \\
\text { tendency to increase, more } \\
\text { than the average rate of } \\
1.0-2.0 \mathrm{~m} \text { per year }\left(^{*}\right)\end{array}$ & [163] \\
\hline & $\begin{array}{l}\text { Freezing of coolant lines to } \\
\text { a chemical reaction vessel }\end{array}$ & Medium & $<0^{\circ} \mathrm{C}$ & [84] \\
\hline & $\begin{array}{c}\text { Cycles of freezing and } \\
\text { thawing may threaten the } \\
\text { structural integrity of lines } \\
\text { and other processing } \\
\text { equipment }\end{array}$ & Medium & $<0^{\circ} \mathrm{C}$ & [164] \\
\hline & $\begin{array}{l}\text { Oil pipelines (burst pipes } \\
\text { or failures of pipelines) }\end{array}$ & Medium & $(*)$ & [40] \\
\hline & $\begin{array}{l}\text { Electricity lines/hydrogen } \\
\text { plant/distillation } \\
\text { equipment/fluidic catalytic } \\
\text { cracking unit damages }\end{array}$ & \multirow[t]{2}{*}{ High } & $-7.2^{\circ} \mathrm{C}$ & [86] \\
\hline & $\begin{array}{l}\text { Working conditions, } \\
\text { maintenance jobs at oil } \\
\text { extraction sites }\end{array}$ & & $\begin{array}{l}\text { Temperatures in the range of } \\
\qquad-30{ }^{\circ} \mathrm{C}\end{array}$ & [74] \\
\hline \multirow{3}{*}{$\begin{array}{l}\text { Precipitation } \\
\text { (rain/snowfall)- } \\
\text { humidity }\end{array}$} & Storage tanks & Medium & $\begin{array}{c}\text { Failure and loss of } \\
\text { containment of the storage } \\
\text { tanks contents }\left(^{*}\right)\end{array}$ & [40] \\
\hline & $\begin{array}{l}\text { Drainage systems to } \\
\text { remove spills \& the fire } \\
\text { protection system }\end{array}$ & High & $\begin{array}{l}\text { Threshold: rainfall of } 1 \mathrm{~h} \\
\text { rainfall with a } 1.0 \% \text { chance of } \\
\text { exceedance in } 100 \text { year period }\end{array}$ & [147] \\
\hline & $\begin{array}{l}\text { Flooding and damaging } \\
\text { indirectly several of the } \\
\text { transportation modes, } \\
\text { leading to oil } \\
\text { transportation/distribution } \\
\text { interruptions and delays }\end{array}$ & Medium & $\begin{array}{l}50 \mathrm{~mm} / 24 \mathrm{~h} \text { are able to flood } \\
\text { roads, } 100 \mathrm{~mm} / 24 \mathrm{~h} \text { can pose } \\
\text { issues to street traffic, } \\
\text { reducing visibility and } \\
\text { flooding passageways. At } 150 \\
\mathrm{~mm} / 24 \mathrm{~h} \text {, road constructions } \\
\text { might cause failure, whilst } \\
\text { bridges can be flooded, and } \\
\text { roads might be inundated }\end{array}$ & {$[40,94,135]$} \\
\hline
\end{tabular}


Table A1. Cont.

\begin{tabular}{|c|c|c|c|c|}
\hline Hazard & Type of Asset/Per-Process & $\begin{array}{c}\text { Vulnerability } \\
\text { (H/M/L) }\end{array}$ & Threshold & Source \\
\hline \multirow{11}{*}{$\begin{array}{c}\text { High } \\
\text { winds/Hurricanes }\end{array}$} & Pipelines & High & $26 \mathrm{~m} / \mathrm{s}$ & \multirow{5}{*}{ [92] } \\
\hline & Large vessels & Low & $10 \mathrm{~m} / \mathrm{s}$ & \\
\hline & Large vessels & High & $25 \mathrm{~m} / \mathrm{s}$ & \\
\hline & $\begin{array}{l}\text { Shipping containers/portal } \\
\text { cranes }\end{array}$ & Low & $12 \mathrm{~m} / \mathrm{s}$ & \\
\hline & High-speed ferries & Low & $20 \mathrm{~m} / \mathrm{s}$ & \\
\hline & $\begin{array}{l}\text { Overhead transmission \& } \\
\text { distribution lines }\end{array}$ & High & $30 \mathrm{~m} / \mathrm{s}$ & [100] \\
\hline & \multirow{2}{*}{ Industrial buildings } & \multirow{2}{*}{ High } & 3 -sec wind gusts, 52 to $66 \mathrm{~m} / \mathrm{s}$ & [165] \\
\hline & & & $\begin{array}{l}\text { Damages start from } 30-33 \mathrm{~m} / \mathrm{s} \\
\text { Total failures from } 52-55 \mathrm{~m} / \mathrm{s}\end{array}$ & [82] \\
\hline & Offshore platforms & High & $73 \mathrm{~m} / \mathrm{s}$ & [121] \\
\hline & Offshore structures & High & $\begin{array}{l}\text { A return period of } 100 \text { years } \\
\text { corresponds: to } 41 \mathrm{~m} / \mathrm{s} \text { in } 1-\mathrm{h} \\
\text { average winds or around } 50 \\
\mathrm{~m} / \mathrm{s} \text { in constant } 1 \mathrm{~min} \text { winds } \\
\text { and a wave height of } 22.0 \mathrm{~m}\end{array}$ & [166-168] \\
\hline & $\begin{array}{l}\text { Port (taller constructions } \\
\text { have to be closed) }\end{array}$ & Medium & $9 \mathrm{~m} / \mathrm{s}$ & [88] \\
\hline \multirow[t]{3}{*}{ Lightning strikes } & $\begin{array}{l}\text { Platforms (damages to } \\
\text { electrical systems, loss of } \\
\text { equipment, function and } \\
\text { production) }\end{array}$ & Small & $\begin{array}{c}1 \text { strike could cause damage } \\
\text { and lead to workers } \\
\text { evacuation }\left(^{*}\right)\end{array}$ & [118] \\
\hline & Storage tanks & Small & Highly exposed $\left(^{*}\right)$ & [169] \\
\hline & Employees & Small & $(*)$ & [131] \\
\hline \multirow[t]{3}{*}{$\begin{array}{l}\text { Sea level rise } \\
\text { (SLR) }\end{array}$} & Refineries & High & $\begin{array}{l}\text { Given a category } 1 \text { hurricane, } \\
\text { an SLR }<0.5 \mathrm{~m} \text { almost doubles } \\
\text { the number of refineries } \\
\text { exposed to flooding by } 2100 \text {, } \\
\text { under the Representative } \\
\text { Concentration Pathway } \\
\text { (RCP4.5) scenario }\end{array}$ & {$[65,170,171]$} \\
\hline & $\begin{array}{l}\text { Wastewater treatment } \\
\text { facilities/oil refineries }\end{array}$ & Medium & $\begin{array}{l}\text { Simulations show that for a } \\
\text { return period of a } 100 \text {-yr flood } \\
\text { event and } 1.5 \text { m of SLR, } \\
\text { moderate damages might } \\
\text { occur }\end{array}$ & [172] \\
\hline & $\begin{array}{l}\text { Oil facilities sitting next to } \\
\text { coastline }\end{array}$ & High & $<3 \mathrm{~m}$ above the high tide line & [173] \\
\hline \multirow{3}{*}{$\begin{array}{c}\text { Storm } \\
\text { surges/waves }\end{array}$} & Offshore pipeline & High & Wave height: $1.0-1.2 \mathrm{~m}$ & [135] \\
\hline & Offshore platforms & High & $\begin{array}{l}27.0 \mathrm{~m} \text { horizontal pressure } \\
\text { results in the failure of } \\
\text { structure }\end{array}$ & [174] \\
\hline & $\begin{array}{l}\text { Refineries (flood } \\
\text { protection system) }\end{array}$ & High & $\begin{array}{l}\text { Oil spills, as storm surges from } \\
\text { hurricanes have reached } 8.5 \mathrm{~m}\end{array}$ & [77] \\
\hline
\end{tabular}


Table A1. Cont.

\begin{tabular}{|c|c|c|c|c|}
\hline Hazard & Type of Asset/Per-Process & $\begin{array}{c}\text { Vulnerability } \\
\text { (H/M/L) }\end{array}$ & Threshold & Source \\
\hline \multirow{5}{*}{ Flash Flooding } & Electrical equipment & High & $\begin{array}{l}\text { Functionality threshold }>0.3 \\
\text { m (inundation depth) }\end{array}$ & \multirow{2}{*}{ [81] } \\
\hline & $\begin{array}{l}\text { Small, medium, and large } \\
\text { refineries }\end{array}$ & High & $\begin{array}{c}\text { Functionality threshold depth } \\
\text { to be set at } 1.2 \mathrm{~m} \text {. }\end{array}$ & \\
\hline & $\begin{array}{l}\text { Drainage system } \\
\text { (triggering fire) }\end{array}$ & Medium & $\begin{array}{c}\text { Water level @ } 1.5 \mathrm{~m} \text { inside the } \\
\text { refinery }\end{array}$ & [77] \\
\hline & Control station & Medium & $\begin{array}{l}40.0 \% \text { percentage of damage } \\
\text { after } 0.3 \mathrm{~m} \text { (inundation depth) }\end{array}$ & \multirow[b]{2}{*}{ [81] } \\
\hline & Oil pumping stations & Medium & $\begin{array}{c}\text { Damage starts after } 0.3 \mathrm{~m} \text { of } \\
\text { inundation depth. From } \\
1.8-3.0 \mathrm{~m} \text { at } 40.0 \% \text { percentage } \\
\text { of damage }\end{array}$ & \\
\hline Forest fires & $\begin{array}{l}\text { Distribution lines, Extra } \\
\text { High Voltage (EHV) } \\
\text { transmission lines located } \\
\text { inside or outside the } \\
\text { refinery }\end{array}$ & Small & $\begin{array}{c}\text { Risk comes from smoke and } \\
\text { particulate matter deposition: } \\
\text { PM2.5 concentration is }>350 \\
\mu \mathrm{g} / \mathrm{m}^{3}\end{array}$ & {$[78,80]$} \\
\hline \multirow{2}{*}{ Drought } & $\begin{array}{l}\text { Thermal plant/cooling } \\
\text { systems/oil extraction \& } \\
\text { production }\end{array}$ & Small & Threshold: $\left({ }^{*}\right)$ & [91] \\
\hline & Barge & Low & $\begin{array}{c}0.025 \mathrm{~m} \text { drop in river level: } \\
\text { decrease towing capacity by } \\
255 \text { tons }\end{array}$ & [111] \\
\hline$(*)$ & \multicolumn{4}{|c|}{ Threshold value still not defined in the literature } \\
\hline$(* *)$ & \multicolumn{4}{|c|}{ Depends on climatic conditions and region } \\
\hline
\end{tabular}

\section{References}

1. EEA. The Energy Sector; European Environment Agency: Copenhagen, Denmark, 2008.

2. Eurostat Oil and Petroleum Products-A Statistical Overview. Available online: https://ec.europa.eu/eurostat/ statistics-explained/index.php/Oil_and_petroleum_products_-_a_statistical_overview\#Imports_of_crude_oil (accessed on 25 January 2019).

3. Sfetsos, A.; Katopodis, T.; Eleftheriadou, A.; Eftychidis, G.; Gkotsis, I.; Leventakis, G.; Shakou, M.L. How Interconnected Critical Infrastructures Can Support Societal Resilience under Future Climate: The EU-CIRCLE Approach. National Institute of Standards and Technology-NIST-: RESILIENCE. In Proceedings of the 2nd International Workshop on Modelling of Physical, Economic and Social Systems for Resilience Assessment 2017, Ispra, Italy, 14-16 December 2017; Publications Office of the European Union: Luxembourg, 2017; Volume JRC, NIST.

4. Forzieri, G.; Bianchi, A.; Silva, F.B.; Marin Herrera, M.A.; Leblois, A.; Lavalle, C.; Aerts, J.C.J.H.; Feyen, L. Escalating impacts of climate extremes on critical infrastructures in Europe. Glob. Environ. Chang. 2018, 48, 97-107. [CrossRef] [PubMed]

5. European Commission. Natech Accidents When Natural Disasters Trigger Technological Accidents; European Commission: Ispra, Italy, 2012.

6. French Ministry for Sustainable Development the "NaTech" Risk, or Technological Accidents Triggered by a Natural Event; French Ministry for Sustainable Development: Paris, France, 2013.

7. Necci, A.; Girgin, S.; Krausmann, E. Understanding Natech Risk Due to Storms-Analysis, Lessons Learned and Recommendations; JRC Technical Reports; Publications Office of the European Union: Luxembourg, 2018.

8. Hasan, S.; Foliente, G. Modeling Infrastructure System Interdependencies and Socioeconomic Impacts of Failure in Extreme Events: Emerging R\&D Challenges. Nat. Hazards 2015, 78, 2143-2168.

9. UNISDR. 2009 UNISDR Terminology on Disaster Risk Reduction; UNISDR: Geneva, Switzerland, 2009.

10. EU-Circle Description of Action. Available online: http://www.eu-circle.eu/about/what-is-eu-circle/ (accessed on 10 December 2018). 
11. Auld, H.E. Adaptation by Design: The Impact of Changing Climate on Infrastructure. J. Henry Stewart Publ. 2003, 1, 276-288.

12. Connor, T.; Niall, R.; Cummings, P.; Papillo, M. Incorporating climate change adaptation into engineering design concepts and solutions. Aust. J. Struct. Eng. 2013, 14, 125-134. [CrossRef]

13. Sfetsos, A.; Vamvakeridou, L.S.; Chen, A.S.; Khoury, M.; Savic; Djordjevic, S.; Eftychidis, G.; Abel, G.; Karavokyros, G.; Koutiva, I.; et al. Enhancing the resilience of interconnected critical infrastructures to climate hazards. In Proceedings of the 15th International Conference on Environmental Science and Technology, Rhodes, Greece, 31 August-2 September 2017.

14. Means, E.G.; Laugier, M.C.; Daw, J.A.; Owen, D.M. Impacts of climate change on infrastructure planning and design:Past practices and future needs. J. Am. Water Works Assoc. 2010, 102, 56-65. [CrossRef]

15. DOE. Climate Change and the Electricity Sector Guide for Climate Change Resilience Planning; DOE: Washington, DC, USA, 2016.

16. Department of Homeland Security. Infrastructure Taxonomy; Department of Homeland Security: Washington, DC, USA, 2008.

17. European Commission. Commission Staff Working Document Overview of Natural and Man-Made Disaster Risks in the EU, Brussels, 8.4.2014, SWD(2014) 134 Final; European Commission: Brussels, Belgium, 2014.

18. European Commission. Summary of the Impact Assessment SWD(2013) 131 Final; European Commission: Brussels, Belgium, 2013.

19. IPCC. Final Draft IPCC WGII AR5 Chapter 14; IPCC: Geneva, Switzerland, 2014.

20. European Commission. Adapting Infrastructure to Climate Change; European Commission: Brussels, Belgium, 2013.

21. EEA. National Climate Change Vulnerability and Risk Assessments in Europe, 2018; EEA: Copenhagen, Denmark, 2018; ISBN 978-92-9213-940-7.

22. OECD. Innovative Approaches to Building Resilient Coastal Infrastructure; OECD: Paris, France, 2018.

23. Oil Search. Climate Change Resilience Report; USA, 2017. Available online: https://www.oilsearch. com/_data/assets/pdf_file/0005/18968/OSL-Climate-Change-Resilience-Report_FINAL.pdf (accessed on 10 November 2018).

24. Vallejo, L.; Mullan, M. Climate-Resilient Infrastructure: Getting the Policies Right; OECD: Paris, France, 2017.

25. Cozzani, V.; Campedel, M.; Renni, E.; Krausmann, E. Industrial accidents triggered by flood events: Analysis of past accidents. J. Hazard. Mater. 2010, 175, 501-509. [CrossRef]

26. Petrova, E.G. Natural factors of technological accidents: The case of Russia. Nat. Hazards Earth Syst. Sci. 2011, 11, 2227-2234. [CrossRef]

27. Rasmussen, K. Natural events and accidents with hazardous materials. J. Hazard. Mater. 1995, 40, 43-54. [CrossRef]

28. Santella, N.; Steinberg, L.J.; Aguirra, G.A. Empirical Estimation of the Conditional Probability of Natech Events Within the United States: Empirical Estimation of the Conditional Probability of Natech Events. Risk Anal. 2011, 31, 951-968. [CrossRef]

29. Young, S.; Balluz, L.; Malilay, J. Natural and technologic hazardous material releases during and after natural disasters: A review. Sci. Total Environ. 2004, 322, 3-20. [CrossRef]

30. Krausmann, E.; Baranzini, D. Natech risk reduction in the European Union. J. Risk Res. 2012, 15, $1027-1047$. [CrossRef]

31. Climate Change 2007: Impacts, Adaptation and Vulnerability. In Contribution of Working Group II to the 4th Assessment Report of the Intergovernmental Panel on Climate Change; Parry, M.L.; Canziani, O.F.; Palutikof, J.P.; van der Linden, P.J.; Hanson, C.E. (Eds.) Cambridge University Press: Cambridge, UK, 2007; Volume 4.

32. European Commission. Commission Staff Working Document on the Review of the European Programme for Critical Infrastructure Protection (EPCIP). SWD(2012) 190 Final; European Commission: Brussels, Belgium, 2012.

33. Renni, E.; Basco, A.; Busini, V.; Cozzani, V.; Krausmann, E.; Rota, R.; Salzano, E. Awareness and Mitigation of Natech Accidents: Toward a Methodology for Risk AssessmentClimate Change and International Security. Chem. Eng. Trans. 2010, 119, 383-389.

34. Cruz, A.M.; Steinberg, L.J.; Vetere-Arellano, A.L. Emerging Issues for Natech Disaster Risk Management in Europe. J. Risk Res. 2006, 9, 483-501. [CrossRef] 
35. Donkov, D. Natech Disaster Risk Management on the Territory of Bulgaria; Arellano, A.L.V., Cruz, A.M., Nordvik, J.P., Pisano, F., Eds.; NEDIES International Workshop on Natech (Natural Disaster-Triggered Technological Disasters) Disaster Management: Ispra, Italy, 2004.

36. Vallee, A. Natech Disaster Risk Management in France; Arellano, A.L.V., Cruz, A.M., Nordvik, J.P., Pisano, F., Eds.; NEDIES International Workshop on Natech (Natural Disaster-Triggered Technological Disasters) Disaster Management: Ispra, Italy, 2004.

37. Zaayenga, B. Natech Disaster Risk Management in Bavaria; Arellano, A.L.V., Cruz, A.M., Nordvik, J.P., Pisano, F., Eds.; NEDIES International Workshop on Natech (Natural Disaster-Triggered Technological Disasters) Disaster Management: Ispra, Italy, 2004.

38. Floridi, L. Information System for the Mitigation and Reduction of the Consequences of Accidental Events; Arellano, A.L.V., Cruz, A.M., Nordvik, J.P., Pisano, F., Eds.; NEDIES International Workshop on Natech (Natural Disaster-Triggered Technological Disasters) Disaster Management: Ispra, Italy, 2004.

39. Venancio, C. Natech Risk Management in Portugal; Arellano, A.L.V., Cruz, A.M., Nordvik, J.P., Pisano, F., Eds.; NEDIES International Workshop on Natech (Natural Disaster-Triggered Technological Disasters) Disaster Management: Ispra, Italy, 2004.

40. CIA. Safeguarding Chemical Businesses in a Changing Climate. How to Prepare a Climate Change Adaptation Plan; Chemical Industries Association: London, UK, 2015.

41. Norwegian Ministry of Finance. Climate Risk and the Norwegian Economy; Norwegian Ministry of Finance: Oslo, Norway, 2018.

42. EURACOM. European Risk Assessment and COntingency Planning Methodologies for Interconnected Energy Networks. Available online: https://cordis.europa.eu/project/rcn/92076/factsheet/en (accessed on 12 February 2019).

43. Utne, I.B.; Hokstad, P.; Kjølle, G.; Vatn, J.; Tøndel, I.A.; Bertelsen, D.; Fridheim, H.; Røstum, J. Risk and Vulnerability Analysis of Critical Infrastructures-The DECRIS Approach. In Proceedings of the SAMRISK Conference, Oslo, Norway, 1-2 September 2008.

44. EU-CIRCLE. Case Study 2 EU-CIRCLE Case Study: Multihazard Risk Assessment in Vasilikos Area; Cyprus, 2018. Available online: http://www.eu-circle.eu/research/case-studies/case-study-2/ (accessed on 7 January 2019).

45. Lempert, R.J.; Arnold, J.R.; Pulwarty, R.S.; Gordon, K.; Greig, K.; Hawkins-Hoffman, C.; Sands, D.; Werrell, C. Chapter 28: Adaptation Response. Impacts, Risks, and Adaptation in the United States: The Fourth National Climate Assessment, Volume II; U.S. Global Change Research Program: Washington, DC, USA, 2018.

46. EPA. Climate Change Adaptation Plan; U.S. Environmental Protection Agency: Washington, DC, USA, 2014.

47. Northeastern British Columbia. Climate Risk Assessment for the Oil E Gas Sector; Northeastern British Columbia: Columbia, UK, 2015.

48. ConocoPhillips Managing Climate-Related Risks_Building a Resilient Strategy for the Energy Transition; USA, 2019. Available online: https://static.conocophillips.com/files/resources/climate-change-report.pdf (accessed on 7 May 2019).

49. Acclimatise Understanding the Investment Implications of Adapting to Climate Change-Oil and Gas; Oxford, UK, 2009. Available online: https:/unfccc.int/files/adaptation/adverse_effects/application/pdf/acclimatise_uss_ oil_and_gas_final_report_oct09.pdf (accessed on 5 March 2018).

50. IPIECA. Addressing Adaptation in the Oil and Gas Industry; IPIECA: London, UK, 2013.

51. Smith, M.H. Assessing Climate Change Risks and Opportunities for Investors Oil and Gas Sector; Australian National University: Canberra, Australia, 2013.

52. TC Energy. Delivering Energy Responsibly—Report on Sustainability and Climate Change; TC Energy: Calgary, AB, Canada, 2019.

53. WBCSD. Climate-Related Financial Disclosure by Oil and Gas Companies: Implementing the TCFD Recommendations; WBCSD: Geneva, Switzerland, 2018.

54. Carlson, C.; Goldman, G.; Dahl, K. Stormy Seas, Rising Risks What Investors Should Know About Climate Change Impacts at Oil Refineries; Center for Science and Democracy at the Union of Concerned Scientists: Washington, DC, USA, 2015.

55. Udie, J.; Bhattacharyya, S.; Ozawa-Meida, L. A Conceptual Framework for Vulnerability Assessment of Climate Change Impact on Critical Oil and Gas Infrastructure in the Niger Delta. Climate 2018, 6, 11. [CrossRef] 
56. Dawson, R.J. Handling Interdependencies in Climate Change Risk Assessment. Climate 2015, 3, $1079-1096$. [CrossRef]

57. DOE. Strategic Sustainability Performance Plan; DOE: Washington, DC, USA, 2012.

58. Rinaldi, S.M.; Peerenboom, J.P.; Kelly, T.K. Identifying, understanding, and analyzing critical infrastructure interdependencies. IEEE Control Syst. Mag. 2001, 21, 11-25.

59. Rehak, D. Quantitative evaluation of the synergistic effects of failures in a critical infrastructure system. Int. J. Crit. Infrastruct. Prot. 2016, 15, 3-17. [CrossRef]

60. Grenzeback, L.R.; Lukmann, A.T. Case Study of the Transportation Sector's Response to and Recovery from Hurricanes Katrina and Rita; Transportation Research Board (TRB): Cambridge Systematics Inc.: Cambridge, UK, 2008.

61. Kulesa, G. Weather and Aviation: How Does Weather Affect the Safety and Operations of Airports and Aviation, and How Does FAA Work to Manage Weather-related Effects? In The Potential Impacts of Climate Change on Transportation, Federal Research Partnership Workshop; U.S. Department of Transportation (DOT): San Francisco, CA, USA, 2002; pp. 199-208.

62. EIA. Hurricane Harvey Caused U.S. Gulf Coast Refinery Runs to Drop, Gasoline Prices to Rise. Available online: https://www.eia.gov/todayinenergy/detail.php?id=32852 (accessed on 2 July 2019).

63. Kalghatgi, G.; Levinsky, H.; Colket, M. Future transportation fuels. Prog. Energy Combust. Sci. 2018, 69, 103-105. [CrossRef]

64. BP Demand by Sector-Industry. Available online: https://www.bp.com/en/global/corporate/energyeconomics/energy-outlook/demand-by-sector/industry.html (accessed on 15 November 2019).

65. Zamuda, C.D.; Bilello, D.; Conzelmann, G.; Avery, C.W.; Mecray, E.; Satsangi, A.; Tidwell, V.; Walker, B.J. Chapter 4: Energy Supply, Delivery, and Demand. Impacts, Risks, and Adaptation in the United States: The Fourth National Climate Assessment; U.S. Global Change Research Program: Washington, DC, USA, 2018; Volume II.

66. EIA. Fuel Consumed at Refineries. Available online: https://www.eia.gov/opendata/qb.php?sdid=PET.8_ NA_8FE0_NUS_K.A (accessed on 25 January 2019).

67. European Commission. Communication from the Commission to the European Parliament and the Council_SWD(2014) 330 Final; European Commission: Brussels, Belgium, 2014.

68. Eurostat Consumption of Energy. Available online: https://ec.europa.eu/eurostat/statistics-explained/index. php/Consumption_of_energy (accessed on 27 December 2018).

69. Sanders, K.T.; Webber, M.E. Evaluating the energy consumed for water use in the United States. Environ. Res. Lett. 2012, 7, 34034. [CrossRef]

70. Sun, P.; Elgowainy, A.; Wang, M.; Han, J.; Henderson, R.J. Estimation of U.S. refinery water consumption and allocation to refinery products. Fuel 2018, 221, 542-557. [CrossRef]

71. Wilbanks, T.; Bhatt, V.; Bilello, D.; Bull, S.; Ekmann, J.; Horak, W.; Huang, Y.J.; Levine, M.D.; Sale, M.J.; Schmalzer, D.; et al. Effects of Climate Change on Energy Production and Use in the United States; US Department of Energy Publications: Washington, DC, USA, 2008; p. 12.

72. US Oil Firm's Bid to Drill for Oil in Arctic Hits Snag: A Lack of Sea Ice. Available online: https: //www.theguardian.com/environment/2018/nov/15/arctic-oil-drilling-texas-hilcorp-beaufort-sea (accessed on 22 December 2018).

73. Savonis, M.J.; Burkett, V.R.; Potter, J.R. Impacts of Climate Change and Variability on Transportation Systems and Infrastructure: Gulf Coast Study, Phase I; U.S. Climate Change Science Program: Washington, DC, USA, 2008.

74. Cruz, A.M.; Krausmann, E. Vulnerability of the oil and gas sector to climate change and extreme weather events. Clim. Chang. 2013, 121, 41-53. [CrossRef]

75. DOE. U.S. Energy Sector Vulnerabilities to Climate Change and Extreme Weather; U.S. Department of Energy: Washington, DC, USA, 2013.

76. The University of Stavanger. Norway's Oil Industry Working in Extreme Conditions; The University of Stavanger: Stavanger, Norway, 2012.

77. Bell, L. Winter Weather Effects. Available online: https://www.ogj.com/articles/print/volume-112/issue-3b/ regular-features/journally-speaking/winter-weather-effects.html (accessed on 22 January 2019).

78. Davis, M.; Clemmer, S. How Climate Change Puts Our Electricity at Risk; Union of concerned scientists Power Failure: USA, 2014; Available online: https:/www.ucsusa.org/sites/default/files/2019-10/Power-Failure-HowClimate-Change-Puts-Our-Electricity-at-Risk-and-What-We-Can-Do.pdf (accessed on 2 September 2018). 
79. U.S. Army Corps of Engineers. Hurricane Frederic Post Disaster Report: 30 August-14 September 1979; US Army Engineer District: Mobile, AL, USA, 1981.

80. Sathaye, J.; Dale, L.; Larsen, P.; Fitts, G.; Koy, K.; Lewis, S.; Lucena, A. Estimating Risk to California Energy Infrastructure from Projected Climate Change; CEC-500-2012-057; California Energy Commission: Sacramento, CA, USA, 2012.

81. FEMA Multi-Hazard Loss Estimation Methodology Flood Model Technical Manual; Department of Homeland Security Federal Emergency Management Agency Mitigation Division: Washington, DC, USA, 2011.

82. Department of Homeland Security FEMA. Multi-Hazard Loss Estimation Methodology Hurricane Model Hazus $^{\circledR}{ }_{-}$MH 2.1 User Manual; Mitigation Division: Washington, DC, USA, 2013.

83. Federal Highway Administration. Climate Change and Extreme Weather Vulnerability Assessment Framework; Federal Highway Administration: Washington DC, USA, 2012; p. 58.

84. Veri, A. Severe Weather and Effect on Refining. Available online: http://www.hosemaster.com/severeweather-effect-refining/ (accessed on 11 July 2018).

85. Brinckerhoff, P. 2010 Base Year Update and Validation of the NYMTC New York Best Practice Model (NYBPM). 2014. Available online: https://www.nymtc.org/LinkClick.aspx?fileticket=8WgNz6e-6dY\%3D\&portalid=0 (accessed on 2 June 2019).

86. Seba, E.U.S. Gulf Coast Refineries Restart after Unusual Cold Snap. Available online: https://www.reuters.com/article/us-refinery-operations-weather/u-s-gulf-coast-refineries-restart-afterunusual-cold-snap-idUSKBN1F62PK (accessed on 15 January 2019).

87. Dell, J.J.; Pasteris, P. Adaptation in the Oil and Gas Industry to Projected Impacts of Climate Change; SPE International: Dunholme, UK, 2010.

88. Garg, A.; Naswa, P.; Shukla, P.R. Energy infrastructure in India: Profile and risks under climate change. Energy Policy 2015, 81, 226-238. [CrossRef]

89. Reed, D.A.; Powell, M.D.; Westerman, J.M. Energy Infrastructure Damage Analysis for Hurricane Rita. Nat. Hazards Rev. 2010, 11, 102-109. [CrossRef]

90. Fletcher, S. OTC: Experts See "New Era" of Hurricane Activity. Oil Gas J. 2006, 104, 22-25.

91. Cruz, A.M. Vulnerability of oil and gas infrastructure to climate change and extreme weather events 2010. Clim. Chang. 2010, 121, 41-53. [CrossRef]

92. OFCM. Office of the Federal Coordinator for Meteorological Services and Weather Information for Surface Transportation: National Needs Assessment Report; U.S. Department of Commerce, National Oceanic and Atmospheric Administration (NOAA): Washington, DC, USA; Office of the Federal Coordinator for Meteorological Services and Supporting Research: Washington, DC, USA, 2002.

93. DOE. Climate Change and Energy Supply and Use; Technical report to the U.S. Department of Energy in Support of the National Climate Assessment; U.S. Department of Energy: Washington, DC, USA, 2012.

94. Chinowsky, P.S.; Price, J.C.; Neumann, J.E. Assessment of climate change adaptation costs for the U.S. road network. Glob. Environ. Chang. 2013, 23, 764-773. [CrossRef]

95. Kanji, M.A.; Cruz, P.T.; Massad, F. Debris flow affecting the Cubatão Oil Refinery, Brazil. Landslides 2008, 5, 71-82. [CrossRef]

96. Schaeffer, R.; Szklo, A.S.; Pereira de Lucena, A.F.; Moreira Cesar Borba, B.S.; Pinheiro Pupo Nogueira, L.; Pereira Fleming, F.; Troccoli, A.; Harrison, M.; Sadeck Boulahya, M. Energy sector vulnerability to climate change: A review. Energy 2012, 38, 1-12. [CrossRef]

97. Rottem, S.V.; Moe, A. Climate change in the north and the oil industry. Fridtjof Nansens Instituit Rapp. 2007, 9, 2007.

98. Girgin, S.; Krausmann, E. Historical analysis of U.S. onshore hazardous liquid pipeline accidents triggered by natural hazards. J. Loss Prev. Process Ind. 2016, 40, 578-590. [CrossRef]

99. Cruz, A.M.; Steinberg, L.J.; Luna, R. Identifying Hurricane-Induced Hazardous Material Release Scenarios in a Petroleum Refinery. Nat. Hazards Rev. 2001, 2, 203-210. [CrossRef]

100. Sueta, H.E.; Shigihara, M.; Grimoni, J.A.B.; Burani, G.F.; Nascimento, W.J.D. Risk analysis associated to lightning in oil refinery construction sites. In Proceedings of the 2010 30th International Conference on Lightning Protection (ICLP), Cagliari, Italy, 13-17 September 2010; pp. 1-6.

101. Levina, E.; Tirpak, D. Adaptation to Climate Change: Key Terms; OECD: Paris, France, 2006.

102. EIA. Much of the Country's Refinery Capacity Is Concentrated along the Gulf Coast. Available online: https://www.eia.gov/todayinenergy/detail.php?id=7170 (accessed on 5 February 2019). 
103. Lenderink, G.; van Meijgaard, E. Increase in hourly precipitation extremes beyond expectations from temperature changes. Nat. Geosci. 2008, 1, 511. [CrossRef]

104. DOE. Comparing the Impacts of Northeast Hurricanes on Energy Infrastructure; U.S. Department of Energy: Washington, DC, USA, 2013. Available online: http://www.energy.gov/downloads/us-energy-sectorvulnerabilities-climate-change-and-extreme-weather (accessed on 22 November 2019).

105. Cruz, A.M.; Kajitani, Y.; Tatano, H. Natech Disaster Risk Reduction: Can Integrated Risk Governance Help? In Risk Governance; Fra.Paleo, U., Ed.; Springer: Dordrecht, The Netherlands, 2015; pp. 441-462. ISBN 978-94-017-9327-8.

106. Kinsman, P.; Lewis, J. Report on a Study of International Pipeline Accidents; HSE Books: Norwich, UK, 2000.

107. Veritas, D.N. Pipeline Damage Assessment from Hurricanes Katrina and Rita in the Gulf of Mexico; Report for the Materials Management Service: Detroit, MI, USA, 2007.

108. Agarwal, M.; Souleyrette, R.R.; Maz, T.H. The weather and its impact on urban freeway traffic operations. In Proceedings of the 85nd annual meeting of the Transportation Research Board, Washington, DC, USA, 22-26 January 2006.

109. Gaythwaite, J.W. Design of Marine Facilities for the Berthing, Mooring, and Repair of Vessels, 2nd ed.; Gaythwaite, J., Ed.; American Society of Civil Engineers (ASCE): Reston, VA, USA, 2004.

110. NRC. Transportation Research Board Special Report 290: Potential Impacts of Climate Change on U.S. Transportation; Transportation Research Board: Washington, DC, USA, 2008.

111. GAO. Climate Change. Energy Infrastructure Risks and Adaptation Efforts; GAO: Washington DC, USA, 2014.

112. Nordam, T.; Dunnebier, D.A.E.; Beegle-Krause, C.; Reed, M.; Slagstad, D. Impact of climate change and seasonal trends on the fate of Arctic oil spills. Ambio 2017, 46, 442-452. [CrossRef] [PubMed]

113. Kaiser, M.J. The impact of extreme weather on offshore production in the Gulf of Mexico. Appl. Math. Model. 2008, 32, 1996-2018. [CrossRef]

114. Cruz, A.M.; Krausmann, E. Hazardous-materials releases from offshore oil and gas facilities and emergency response following Hurricanes Katrina and Rita. J. Loss Prev. Process Ind. 2009, 22, 59-65. [CrossRef]

115. Ruckart, P.Z.; Orr, M.F.; Lanier, K.; Koehler, A. Hazardous substances releases associated with Hurricanes Katrina and Rita in industrial settings, Louisiana and Texas. J. Hazard. Mater. 2008, 159, 53-57. [CrossRef]

116. Santella, N.; Steinberg, L.J.; Sengul, H. Petroleum and Hazardous Material Releases from Industrial Facilities Associated with Hurricane Katrina. Risk Anal. 2010, 30, 635-649. [CrossRef]

117. NOIA Hurricanes and the Offshore Oil and Natural Gas Industry; National Ocean Industries Association: Washington, DC, USA, 2018.

118. Galván, A. A Technical Basis for Guidance of Lightning Protection for Offshore Oil Installations. J. Lightning Res. 2007,3, 9 .

119. Fournier, N.; Guentchev, G.; Krijnen, J.; Saulter, A.; Acton, C.; Hanlon, H. Impact of Climate Change on the North Sea Offshore Energy Sector. In Proceedings of the Volume 7B: Ocean Engineering, ASME, Madrid, Spain, 17-22 June 2018; p. V07BT06A013.

120. Coaster, L. How Oil Industry Redesigned Its Infrastructure for a Rising Sea Level While It Denied Climate Change. Available online: https://www.dailykos.com/stories/2016/1/1/1465357/-How-OilIndustry-redesigned-its-infrastructure-for-a-rising-sea-level-while-it-denied-Climate-Change (accessed on 22 January 2019).

121. Cruz, A.M.; Krausmann, E. Damage to offshore oil and gas facilities following hurricanes Katrina and Rita: An overview. J. Loss Prev. Process Ind. 2008, 21, 620-626. [CrossRef]

122. Energo Engineering, Inc. Assessment of Fixed Offshore Platform Performance in Hurricanes Katrina and Rita, Final Report; Energo Engineering Project No.: E06117; Houston, TX, USA, May 2007. Available online: https://www. bsee.gov/sites/bsee.gov/files/tap-technical-assessment-program/578aa.pdf (accessed on 22 November 2019).

123. Glöckler, O. Effects of Extreme Weather on Nuclear Power Plants; IAEA: Vienna, Austria, 2010.

124. Hulme, M.; Neufeldt, H.; Colyer, H.; Ritchie, A. Adaptation and Mitigation Strategies: Supporting European Climate Policy. The Final Report from the ADAM Project. Revised June 2009, 43. Available online: https:// pdfs.semanticscholar.org/aab2/c5111fb2ad4ea165592f1bac7aa2a3a0d42f.pdf (accessed on 22 November 2019).

125. Sathaye, J.A.; Dale, L.L.; Larsen, P.H.; Fitts, G.A.; Koy, K.; Lewis, S.M.; de Lucena, A.F.P. Estimating impacts of warming temperatures on California's electricity system. Glob. Environ. Chang. 2013, 23, 499-511. [CrossRef]

126. Chang, J.I.; Lin, C.C. A Study of Storage Tank Accidents. J. Loss Prev. Process Ind. 2006, 19, 51-59. [CrossRef] 
127. DOE. Climate Change and the U.S. Energy Sector: Regional Vulnerabilities and Resilience Solutions; US Department of Energy: Washington, DC, USA, 2015.

128. Renni, E.; Krausmann, E.; Cozzani, V. Industrial accidents triggered by lightning. J. Hazard. Mater. 2010, 184, 42-48. [CrossRef] [PubMed]

129. Steinberg, L.J.; Sengul, H.; Cruz, A.M. Natech risk and management: An assessment of the state of the art. Nat. Hazards 2008, 46, 143-152. [CrossRef]

130. CDC. Workplace Safety and Health Topics-Heat Stress. Available online: https://www.cdc.gov/niosh/topics/ heatstress/ (accessed on 15 December 2018).

131. Coelho, G.H.L.; Paulino, J.O.S.; Moreira, R.K.; Moreira, A.K. Study of lightning protection systems in oil plants due maintenance job: Risk analysis. In Proceedings of the 2011 International Symposium on Lightning Protection, Fortaleza, Brazil, 3-7 October 2011; pp. 62-66.

132. U.S. Climate Resilience Toolkit Building Resilience in Coastal Communities. Available online: https: //toolkit.climate.gov/topics/coastal-flood-risk/building-resilience-coastal-communities (accessed on 20 December 2018).

133. Nadal, N.; Zapata, R.; Pagan, I.; Lopez, R.; Agudelo, J. Building Damage due to Riverine and Coastal Floods. J. Water Resour. Plan. Manag. 2010, 25, 327-336. [CrossRef]

134. Rodahl, K. Occupational Health Conditions in Extreme Environments. Ann. Occup. Hyg. 2003, 47, $241-252$.

135. Federal Highway Administration. U.S. DOT Gulf Coast Study, Phase 2; FHWA-HEP-14-053; Federal Highway Administration: Washington DC, USA, 2016. Available online: https://www.hrpdcva.gov/uploads/docs/7B_ FHWA\%20Summary\%20-\%20Gulf\%20Coast\%20Phase\%202.pdf (accessed on 22 November 2019).

136. Chatzidakis, D.; Tsompanakis, Y.; Psarropoulos, P.N. An improved analytical approach for simulating the lateral kinematic distress of deepwater offshore pipelines. Appl. Ocean Res. 2019, 90, 101852. [CrossRef]

137. Puig, D.; Haselip, J.; Naswa, P. Adaptation to Climate Change in Colombia's Oil and Gas Industry; UNEP DTU Partnership: Copenhagen, Denmark, 2015; p. 46.

138. The Paris Agreement (COP 21); United Nations: Paris, France, 2015.

139. Component Fragility Evaluation and Seismic Safety Assessment of "Special Risk" Petrochemical Plants under Design Basis and Beyond Design Basis Accidents. Available online: http://www.induse2safety.unitn.it/ (accessed on 13 March 2019).

140. Cruz, A.M.; Krausmann, E.; Kato, N.; Girgin, S. Reducing Natech Risk: Structural Measures. In Natech Risk Assessment and Management; Elsevier: Amsterdam, The Netherlands, 2017; pp. 205-225. ISBN 978-0-12-803807-9.

141. Government Publishing Office Code of Federal Regulations (Annual Edition). Available online: https: //www.govinfo.gov/app/collection/cfr (accessed on 15 February 2019).

142. Baskin Brian A Year After Katrina, US Gulf Drillers Rein in Rogue Rigs. Available online: https://www. rigzone.com/news/oil_gas/a/35708/a_year_after_katrina_us_gulf_drillers_rein_in_rogue_rigs/ (accessed on 3 December 2018).

143. IEC. 61892-6 Mobile and fixed offshore units-Electrical installations-Part 6: Installation; IEC: Geneva, Switzerland, 1999.

144. API. Oil and Natural Gas Industry Preparedness Handbook; American Petroleum Institute: Washington, DC, USA, 2016.

145. Essentra How Oil Rigs Make Standard Preparations for Hurricanes. Available online: https:// essentrapipeprotection.com/oil-rigs-make-standard-preparations-hurricanes/ (accessed on 6 January 2019).

146. Foong, O.M.; Sulaiman, S.; Awang Rambli, D.; Syazwani Bt Abdullah, N. ALAP: Alarm Prioritization System For Oil Refinery. In Proceedings of the World Congress on Engineering and Computer Science, San Francisco, CA, USA, 20-22 October 2009; Volume 2179.

147. GAPPS Guidelines. Drainage for Outdoor Oil and Chemical Plants; A Publication of Global Asset Protection Services LLC: Hartford, CT, USA, 2015; p. 8.

148. Necci, A.; Antonioni, G.; Cozzani, V.; Borghetti, A.; Nucci, C.A. Quantification of risk reduction due to the installation of different lightning protection solutions for large atmospheric storage tanks. Chem. Eng. Trans. 2014, 36, 481-486.

149. ASCE. Minimum Design Loads and Associated Criteria for Buildingsand Other Structures; American Society of Civil Engineers: Alexander Bell Drive, Reston, VA, USA, 2016; pp. 20191-24382. ISBN 9780784479964.

150. IEC. Protection Against Lightning_Part 02: Risk Management; IEC: Geneva, Switzerland, 2006. 
151. Srinivas, S. Investors Ask Oil Companies to Disclose Refineries' Risks from Climate Change. Available online: https://www.theguardian.com/sustainable-business/2015/feb/26/climate-change-oil-companies-risknatural-disasters-flooding (accessed on 10 February 2019).

152. Huizinga, J.; Moel, H.; de Szewczyk, W. Global Flood Depth-Damage Functions; European Commission, Joint Research Centre, Edificio Expo: Sevilla, Spain, 2017; p. 114.

153. UK Cabinet Office. Keeping the Country Running: Natural Hazards and Infrastructure; UK Cabinet Office: London, UK, 2011.

154. Scalingi, P.; Steve, F. Infrastructure Interdependencies Lessons Learned for Energy and Regional Resilience; U.S. Department of Energy Interdependencies Workshop: Washington, DC, USA, 2013; Available online: https://www.naseo.org/Data/Sites/1/events/energyassurance/2013-12-02/scalingi-and-folga.pdf (accessed on 23 October 2019).

155. McAllister, T. Guide Brief 5: Assessing Energy System Dependencies; National Institute of Standards and Technology: Gaithersburg, MD, USA, 2016; p. NIST SP 1190GB-5.

156. Varianou Mikellidou, C.; Shakou, L.M.; Boustras, G.; Dimopoulos, C. Energy critical infrastructures at risk from climate change: A state of the art review. Saf. Sci. 2018, 110, 110-120. [CrossRef]

157. EC. EU Policies contributing to Disaster Risk Management; EC: Brussels, Belgium, 2014.

158. EEA. Adaptation in Europe-Addressing Risks and Opportunities from Climate Change in the Context of Socio-Economic Developments; EEA Report No 3/2013; EEA: Copenhagen, Denmark, 2013.

159. IFC. Climate Risk and Business Practical Methods for Assessing Risk; IFC: Washington, DC, USA, 2010.

160. Hoffmann, B.; Häfele, S.; Müller, U.; Karl, U. Analysis of the impact of changing hydrometeorological parameters on the electricity production of once-through cooled thermal power plants in Germany-A System Dynamics modelling approach. In Proceedings of the International Conference on Energy, Environment and Health, Copenhagen, Denmark, 31 May-2 June 2010.

161. OSHA. Process Safety Management for Petroleum Refineries; U.S. Department of Labor Occupational Safety and Health Administration: Washington, DC, USA, 2017.

162. OSHA. Using the Heat Index: A Guide for Employers; U.S. Department of Labor Occupational Safety and Health Administration: Washington, DC, USA, 2014.

163. Novikova, A.; Belova, N.; Baranskaya, A.; Aleksyutina, D.; Maslakov, A.; Zelenin, E.; Shabanova, N.; Ogorodov, S. Dynamics of Permafrost Coasts of Baydaratskaya Bay (Kara Sea) Based on Multi-Temporal Remote Sensing Data. Remote Sens. 2018, 10, 1481. [CrossRef]

164. European Commission. Chemical Accident Prevention \& Preparedness. Natech Accidents; Lessons Learned Bulletin No. 6; Security Technology Assessment Unit European Commission Joint Research Centre Institute for the Protection and Security of the Citizen Via E. Fermi: Ispra, Italy, 2014.

165. American Society of Civil Engineers. ASCE 7 Minimum Design Loads for Buildings and Other Structures; Chapter 6: Wind Loads; American Society of Civil Engineers: Charleston, SC, USA, 2005.

166. Ghonheim, A.; Colby, C. GoM Offshore Structures Design Criteria. 2005. Available online: https://www.scribd. com/document/94121261/GoM-Offshore-Structures-Design-Criteria (accessed on 10 September 2019).

167. Kramek, R.E. Today's Challenges and Opportunities for Innovation. In Proceedings of the Offshore Technology Conference, Houston, TX, USA, 1-4 May 2006.

168. Ward, E.G.; Gilbert, R.; Spong, R. Hurricane Readiness and Recovery Conference: Final Conference Summary Report; Report no. 1005C155; Offshore Technology Research Center: Austin, TX, USA, 2005.

169. Venturino, P.; Booman, J.N.; Gonzalez, M.O.; Otegui, J.L. Pipeline failures due to lightning. Eng. Fail. Anal. 2016, 64, 1-12. [CrossRef]

170. Maloney, M.C.; Preston, B.L. A geospatial dataset for U.S. hurricane storm surge and sea-level rise vulnerability: Development and case study applications. Clim. Risk Manag. 2014, 2, 26-41. [CrossRef]

171. Sweet, W.V.; Horton, R.; Kopp, R.E.; LeGrande, A.N.; Romanou, A. Ch. 12: Sea Level Rise. Climate Science Special Report: Fourth National Climate Assessment, Volume I; U.S. Global Change Research Program: Washington, DC, USA, 2017.

172. Wei, D.; Chatterjee, S. Economic Impact of Sea level Rise to the City of Los Angeles; Price School of Public Policy and Center for Risk and Economic Analysis of Terrorism Events University of Southern California: Los Angeles, CA, USA, 2013; p. 90089. 
173. Strauss, B.; Ziemlinski, R. Sea Level Rise Threats to Energy Infrastructure: A Surging Seas Brief Report by Climate Central; Climate Central: Washington, DC, USA, 2012.

174. Larino, J. Offshore Oil and Gas Industry Adapts, but Risks Remain 10 Years after Katrina. Available online: https://www.nola.com/katrina/index.ssf/2015/08/energy_industry_adapts_but_sto.html (accessed on 19 December 2018).

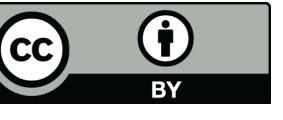

(C) 2019 by the authors. Licensee MDPI, Basel, Switzerland. This article is an open access article distributed under the terms and conditions of the Creative Commons Attribution (CC BY) license (http://creativecommons.org/licenses/by/4.0/). 